Portland State University

PDXScholar

\title{
Preserving Housing Choice and Opportunity: A Study of Apartment Building Sales and Rents
}

\author{
Seyoung Sung \\ Portland State University \\ Lisa K. Bates \\ Portland State University, lkbates@pdx.edu
}

Follow this and additional works at: https://pdxscholar.library.pdx.edu/usp_fac

Part of the Public Policy Commons, Urban Studies Commons, and the Urban Studies and Planning Commons

Let us know how access to this document benefits you.

\section{Citation Details}

Sung, Seyoung and Bates, Lisa K., "Preserving Housing Choice and Opportunity: A Study of Apartment Building Sales and Rents" (2017). Urban Studies and Planning Faculty Publications and Presentations. https://doi.org/10.15760/report-02

This Report is brought to you for free and open access. It has been accepted for inclusion in Urban Studies and Planning Faculty Publications and Presentations by an authorized administrator of PDXScholar. Please contact us if we can make this document more accessible: pdxscholar@pdx.edu. 

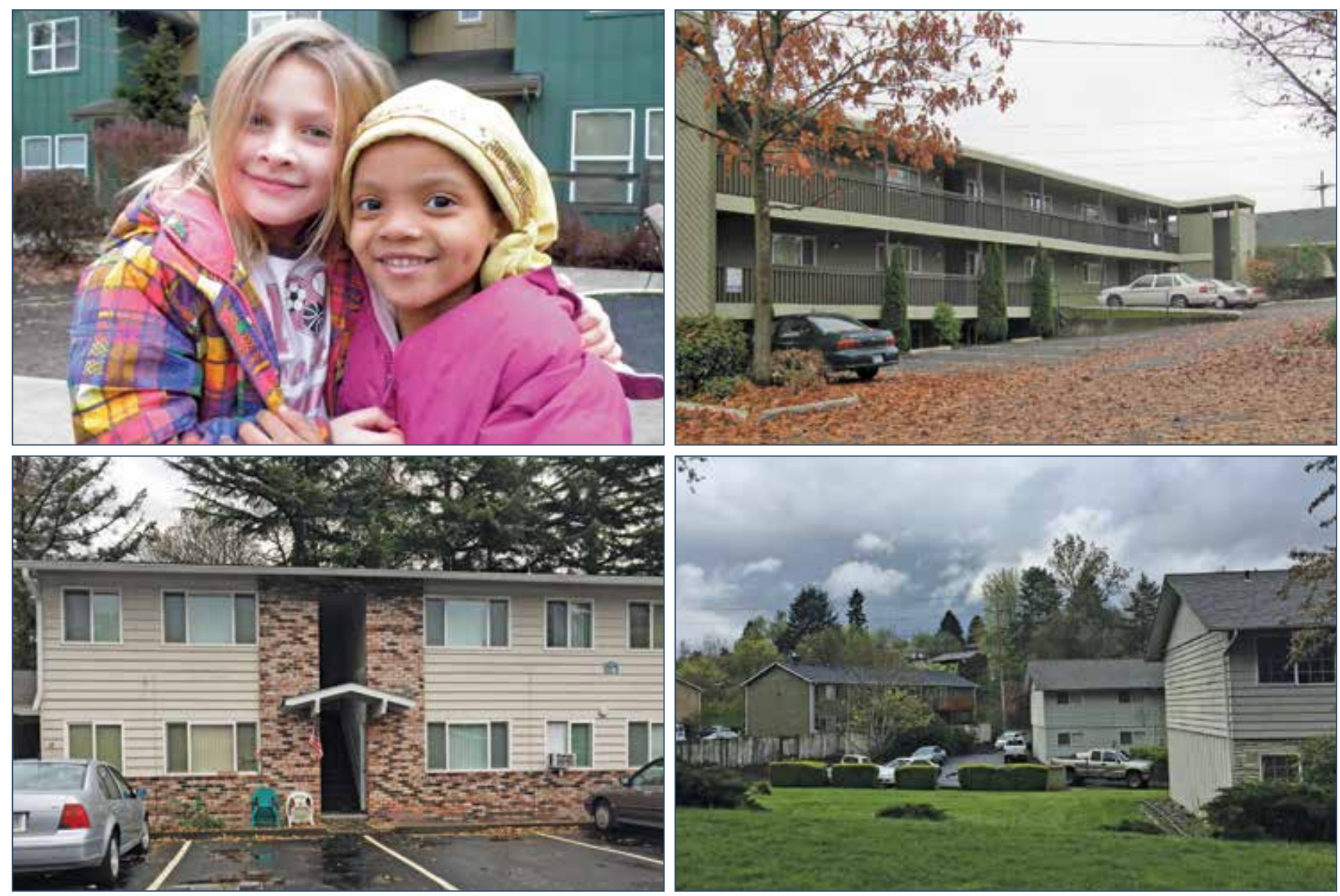

\section{Preserving Housing Choice and Opportunity}

A STUDY OF APARTMENT BUILDING SALES AND RENTS

November 2017

Seyoung Sung and Lisa K. Bates, Ph.D.

Toulan School of Urban Studies And Planning

Portland State University

Prepared for:

Southwest Corridor Equity and Housing Advisory Group
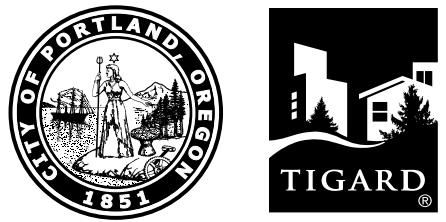


\section{Key Findings}

\section{NOAH sales show precariousness of this rental housing at a regional scale}

- Active transactions of multifamily rental properties have been disproportionately NOAH. There have been over two thousand transactions of NOAH buildings in the Portland metro area from 2006 to 2017 — over 68,000 units of housing. These sales are accelerating, with over 20 percent occurring in just the last 18 months.

- Sales prices for multifamily rental properties have increased substantially, making preservation of affordable rents more challenging. Regionally, the average sale price increased by 78 percent between 2010 and 2017; during this period there was a 43 percent increase in the average asking rent.

- Multifamily housing properties in racially diverse and low-income neighborhoods have been a target for sales activities. Nearly half of the rental units sold were in low-income tracts; and nearly 60 percent were in racially diverse tracts. Almost all of these sales were to two-three star NOAH type properties.

\section{NOAH in the SW Corridor}

- Approximately 11,400 units of naturally occurring affordable housing (NOAH) exist along the Southwest Corridor - 327 properties home to renters with affordable rent. NOAH accounts for 93 percent of existing apartment buildings along the corridor. At the region wide scale, these buildings represents over 9 percent of the market affordable rental units in the metro.

- During the last five years, the corridor shows a split of very low and very high income renter households. After 2010, 81 percent of newly built multifamily housing units in the corridor were luxury apartments. Although 70 percent of units existing in the corridor are currently affordable to families having low- to moderate-income, the recent influx of high income renters and housing market investment made in the corridor suggests that upscaling of $\mathrm{NOAH}$ will become more attractive with the coming public investment in high speed transit.

- Recent apartment sales in SW corridor are increasing, rising in price per unit, and are NOAH type housing. The average sale price along the corridor skyrocketed significantly, with a 274 percent increase.

- When upscaling of NOAH happens along the corridor, the most vulnerable households will be low-income renters of color having large size family. Two-thirds of corridor NOAH sales are in low-income census tracts; nearly 40 percent are in racially diverse areas.

- If we consider NOAH as most susceptible to upscaling, there is the potential for over 11,000 rental units to be re-graded in the corridor. Over four thousand of these units are located in large buildings of over 100 units, with the potential to displace large numbers of renters with one building sale. 


\section{Contents}

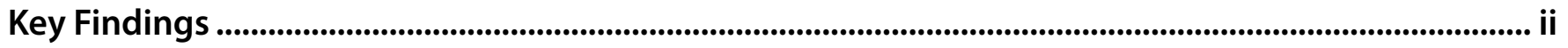

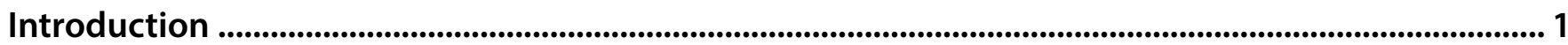

Data and methods................................................................................................................................................. 2

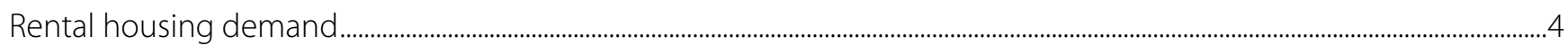

Trend: More renter households and income bifurcation ..........................................................................................................................

Rental Housing Inventory.............................................................................................................................................................................6

Rental housing quality: mid-quality dominates the market .....................................................................................................................................

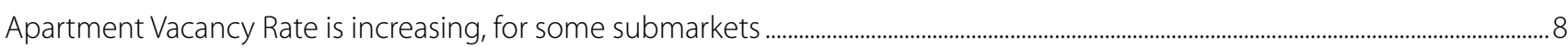

NOAH housing trends differ from high quality housing trends ..............................................................................................................9

Average asking rent by star rating................................................................................................................................................................................12

The geography of NOAH in the Portland region ................................................................................................ 14

Is NOAH in jeopardy in the region? ...................................................................................................................... 15

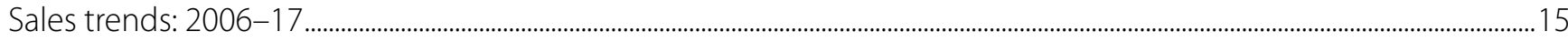

Number of buildings and units sold per year..................................................................................................................................................................... 15

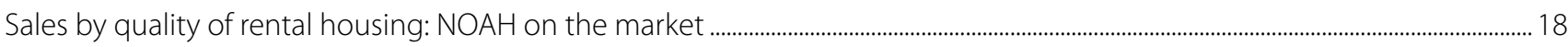

Rising price of rent and per-unit apartment sales, 2010-17 (as of 8/10/17) ...................................................................................................... 19

Very recent market acceleration ................................................................................................................................. 22

Geography of sales .......................................................................................................................................................................................................2

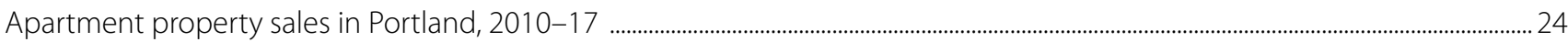

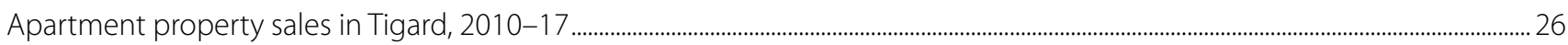

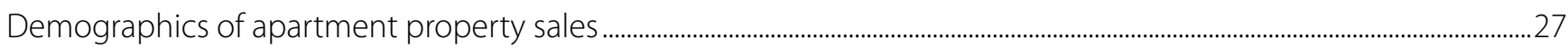

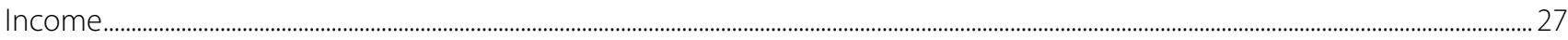

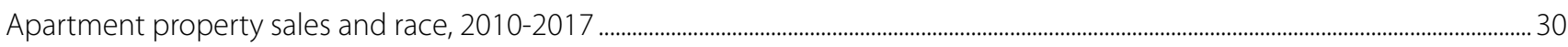

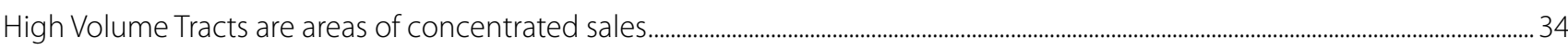

Local Policy Responses to NOAH Preservation Opportunities .........................................................................35

Network for Oregon Affordable Housing's Oregon Housing Acquisition Fund ..........................................................................35

Greater Minnesota Housing Fund's NOAH Impact Fund ..........................................................................................................................36

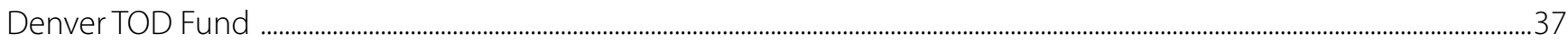

Bay Area Transit Oriented Affordable Housing Fund .......................................................................................................................................

Regional Equitable Development Initiative Fund-Puget Sound .........................................................................................................39

Housing Partnership Equity Trust (HPET) .................................................................................................................................... 40

Austin's Affordable Central Texas Fund .........................................................................................................................................................4

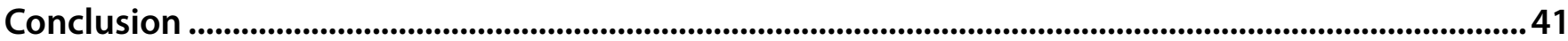




\section{Figures}

Fig.1 - Examples of apartments by CoStar building rating system .......................................................................................................

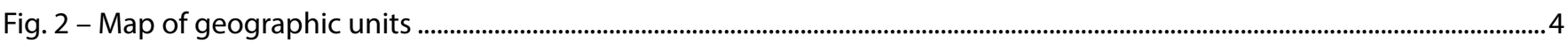

Fig. 3 - Change in household population, 2011-15

Fig. 4 - Change in renter households by income, 2011-15 .........................................................................................................

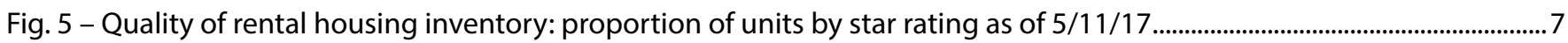

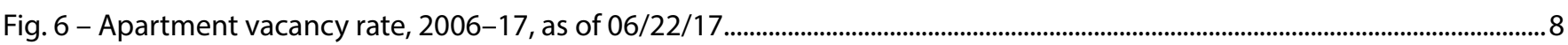

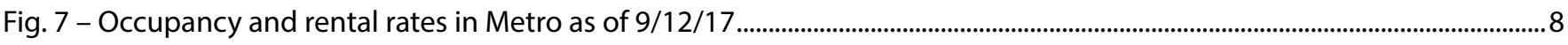

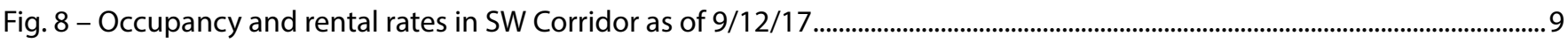

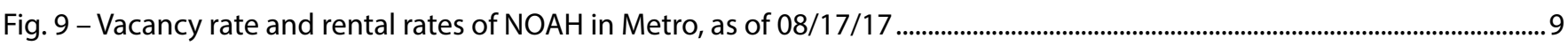

Fig. 10 - Vacancy rate and rental rates of high quality housing in Metro, as of 08/17/17 ...............................................................10

Fig. 11 - Average asking rent per unit, 2006-17 as of 06/22/17 ......................................................................................................11

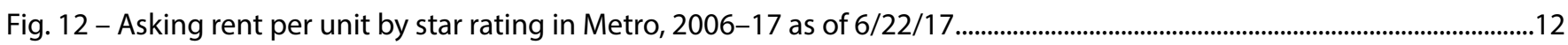

Fig. 13 - Asking rent per unit by star rating in Portland, 2006-17 as of $6 / 22 / 17$..............................................................................12

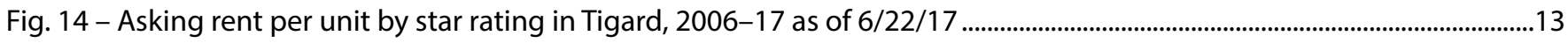

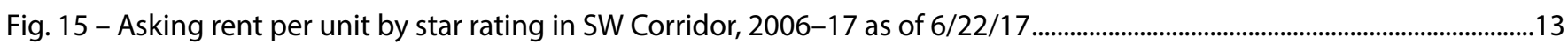

Fig. 16 - Map of NOAH (1,2,3 star apartments) in Metro as of 05/11/17 ........................................................................................14

Fig. 17 - Number of rental housing properties and units sold per year in Metro, 2006-17 as of 8/10/17..................................15

Fig. 18 - Number of rental housing properties and units sold per year in SW Corridor, 2006-2017, as of 8/10/17....................17

Fig. 19 - Number of rental housing properties and units sold per year in Portland, 2006-2017, as of 8/10/17 ..........................17

Fig. 20 - Number of rental housing properties and units sold per year in Tigard, 2006-2017, as of 8/11/17 ...............................18

Fig. 21 - Change in rent and per-unit sale price in Metro, 2010-2017, as of 8/10/17 ...................................................................19

Fig. 22 - Change in rent and per-unit sale price in Portland, 2010-17, as of $8 / 10 / 17$.......................................................................20

Fig. 23 - Change in rent and per-unit sale price in Tigard, 2010-17, as of 8/10/17 ..........................................................................20

Fig. 24 - Change in rent and per-unit sale price in SW Corridor, 2010-17, as of 8/10/17 ..............................................................21

Fig. 25 - Average sale price per unit by star rating between 2006 and 2017 , as of $8 / 10 / 17$.............................................................21

Fig. 26 - Average price per unit of NOAH vs 4 and 5 star properties, 2016-17, as of 8/10/17 .......................................................22

Fig. 27 - Map of rental housing property sales in Metro, 2010-17, as of 8/10/17 ............................................................................23

Fig. 28 - Map of rental housing property sales in Portland, 2010-17 ................................................................................................25

Fig. 29 - Map of rental housing property sales in Tigard, 2010-17 .................................................................................................26

Fig. 30 - Units sold by census tract median income in Metro, 2010-17, as of $8 / 10 / 17$......................................................................2

Fig. 31 - Units sold by census tract median income in Portland, 2010-17, as of 8/10/17 ..............................................................28

Fig. 32 - Units sold by census tract median income in Tigard, 2010-17, as of 8/1017......................................................................28

Fig. 33 - Units sold by census tract median income in SW Corridor, 2010-17, as of 8/10/17.........................................................29

Fig. 34 - Metro: Map of rental housing property sales and percentage of people of color by census tract .................................30

Fig. 35 - Portland: Map of rental housing property sales and percentage of people of color by census tract............................31

Fig. 36 - Tigard: Map of rental housing property sales and percentage of people of color by census tract .................................32

Fig. 37 - SW Corridor: Map of rental housing property sales and percentage of people of color by census tract.......................33

\section{Tables}

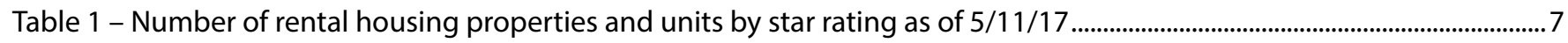

Table 2 - NOAH (1,2,3 stars) and high quality (4,5 stars) housing in Metro, as of 08/17/17 ..............................................................10

Table 3 - NOAH (1,2,3 stars) and high quality (4,5 stars) housing in SW Corridor, as of 08/17/17 ..............................................10

Table 4 - Average number of rental housing properties and units sold per year, 2010-17, as of 8/10/17 ...................................16

Table 5 - Sales percentage for the top 10 cities with the largest share of the region's rental units, 2010-2017 ..........................16

Table 6 - Number of units and properties sold by star rating between 2006 and 2017, as of 8/10/17 ......................................18

Table 7 - Number of units and properties sold between 2016 and 2017, as of 8/10/17 .................................................................22

Table 8 - Sales of rental housing properties and units in Portland by neighborhood, 2010-17, as of 8/10/17 ..........................24 


\section{Introduction}

An important component of the housing stock affordable to lower-income households is unsubsidized, marketprovided rental housing that rents at lower cost. In fact, the great majority of households who are income-eligible for housing subsidies do not receive any government assistance with housing and live in market-rate housing. This sector of the market — commonly called NOAH, or Naturally Occurring Affordable Housing — has increasingly been the focus of policy and programmatic action to protect and expand housing affordability.

In a hot housing market like the Portland region, NOAH type units can be converted and upgraded to higher rent levels. A complex can be purchased to be upgraded and rebranded, especially if it is in a desirable location. This upscaling can displace large numbers of households/families at once; a single real estate transaction could result in the eviction of hundreds of people.

This report focuses on the housing market for lower-income households, specifically on multifamily rental properties that would be the targets of upscaling investments and could displace vulnerable renters. The report describes the current inventory and recent sales activity in lower-quality, lower-cost multifamily rental housing.

The report includes information about the three-county Portland metro area, and focuses on the geography of Southwest Portland and Tigard. As part of the planning for the transit line extension into the Southwest Corridor — from Portland into Tigard — the Southwest Corridor Equity and Housing Advisory Group has been convened to consider how to preserve and expand housing opportunities in newly accessible neighborhoods. As the region plans for a new light rail line, there is an opportunity to address the vulnerabilities for renters in NOAH rental units along the corridor through building preservation. This report contributes information to use in considering policy and programmatic responses to affordable housing loss. In particular, it allows the advisory group to consider questions of scale — how many units might be preserved with different targets — and geography — where might housing be maintained as affordable. 


\section{Data and methods}

This report is patterned after the report Sold Out produced by the Minnesota Housing Partnership in 2016 to address the pace, price, volume, and location of affordable housing loss through market sales. The MHP report, authored by Atticus Jaramillo and Chip Halbach, provides the framework for our analysis and structure of this document. We acknowledge the assistance of MHP staff and partners in providing guidance for this analysis as well as insight into their policy-making process.

The analysis couples market data with demographic information. Starting from 2006, the analysis aims to outline the changing pace of naturally occurring affordable housing (NOAH) and multifamily property sales with a particular focus on the geography of change with respect to vulnerable demographic groups.

The primary datasets for tracking the housing market are the CoStar Multi-Family Property database and CoStar Sales COMPS database in the areas from 2010 through 2016 and to date. American Community Survey data from 2011-15 and 2006-10 were used for the demographic information in this analysis.

The CoStar database includes information on leasing, sales, comparable sales, tenants, and demand statistics. In order to analyze naturally occurring affordable housing (NOAH), the data were extracted from the CoStar MultiFamily Property databases as of May through August 2017. The CoStar Multi-Family Property database provides commercial real estate information, including units for lease, properties for sale, fully-leased inventory, property and market analytics. While the original database includes proposed units and properties that are not currently built in the study area, the analysis here only looks at the existing stock. The CoStar Sales COMPS database provides details of commercial property buying and selling; this report covers arm's length transactions only.

The data cover multi-unit rental housing starting at 5 unit buildings, and does not include single family homes, duplex/quadplex type rental housing. The CoStar data also has limited coverage in small sized rental housing units managed by individuals, not by management companies, although those rental housing units are easily to get converted when gentrification occurs. These are also potentially precarious types of housing, but are not addressed in this report.

Throughout the report, we refer to the CoStar building rating system as a proxy for NOAH type housing. The star rating system used by CoStar is a 5 star scale that is based on the design and construction of buildings and dwelling units and site and property amenities. Buildings with four and five stars are high end and competitive at the high end of the market. The focus for considering NOAH is typically two and three star buildings, which are considered average, somewhat obsolete in terms of design, and with functional and limited amenities. A 1 star building is considered to need significant renovation. See Figure 1 below for a visual representation of the star rating system.

In this analysis, we included one, two and three star buildings as NOAH since the particular focus on this analysis is to seek vulnerability of renters when upscaling or renovation occurs to low quality apartments. The four and five star buildings are considered as high quality apartments. 
Fig. 1 - Examples of apartments by CoStar building rating system
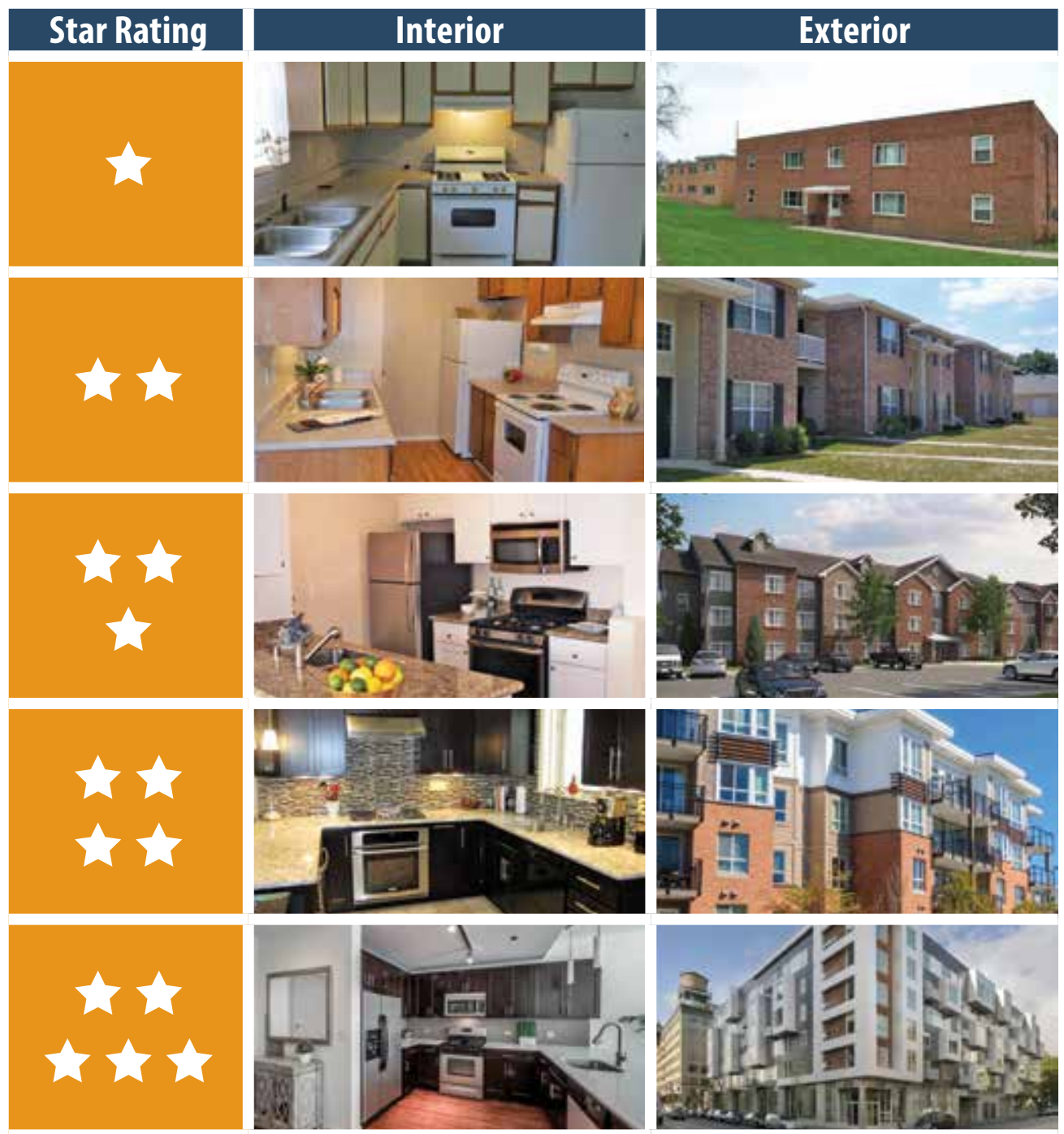

Source: Naturally Occurring Affordable Housing, NAAHL \& ULI Symposium, Oct.2016

The geographic units used in this analysis are Metro, Portland, Tigard, and SW corridor.

Unlike the entire Portland MSA, the geographic unit Metro here includes Multnomah County, Clackamas County, and Washington County.

Analysis of the Southwest Corridor focuses more closely to consider the opportunities and challenges of transitoriented development. Where the data are presented for Southwest Corridor, they are along the alignment for the new development of light rail system connecting SW Portland and Tigard. The census tracts used here for Southwest corridor are derived from the planning documents and shared data source from BPS. 
Fig. 2 - Map of geographic units

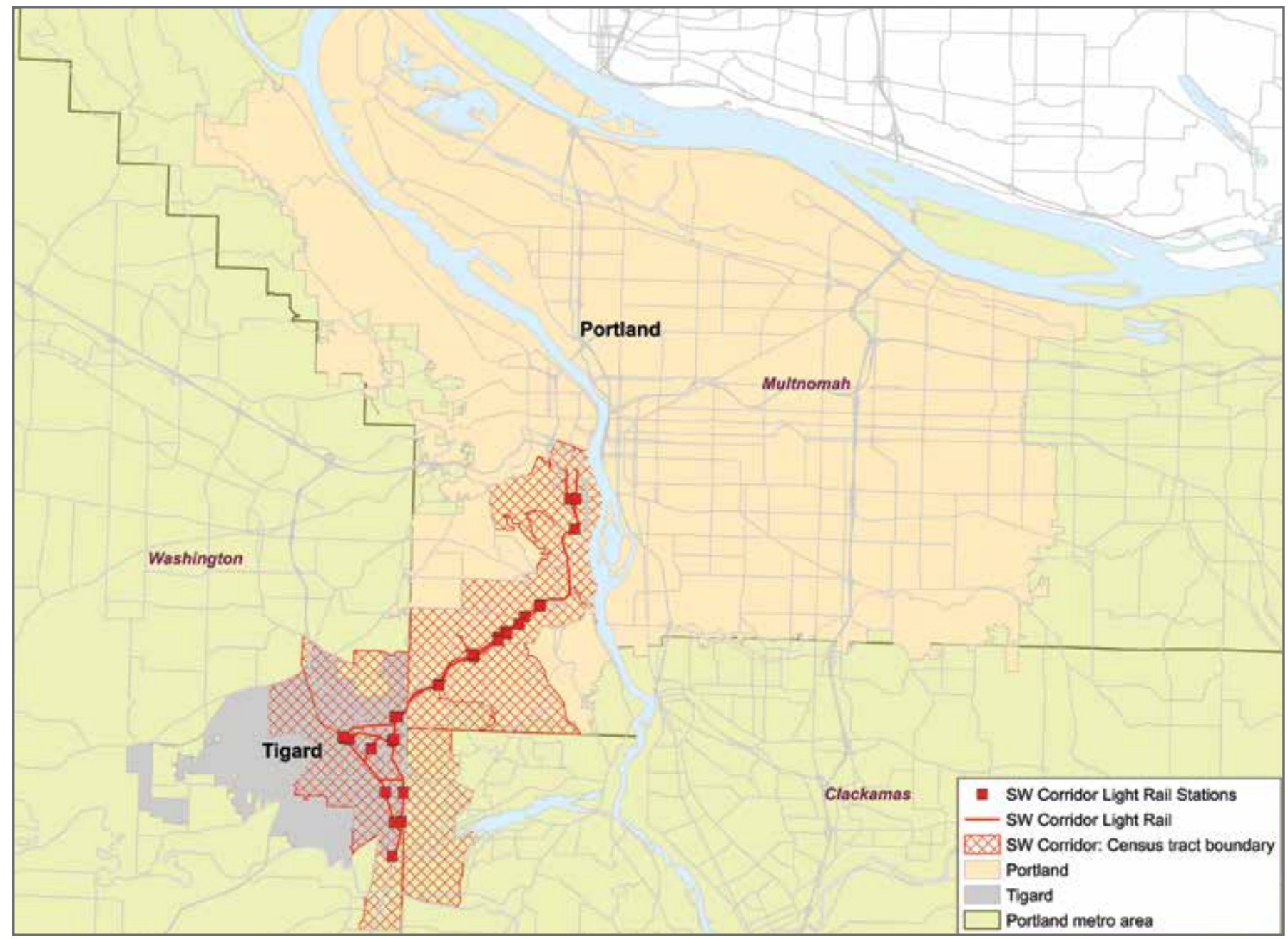

\section{The current state of multifamily rental housing}

\section{Rental housing demand}

\section{Trend: More renter households and income bifurcation}

Portland has been a top destination for relocation due to its unique culture and livability, as well as post-recession job growth. The new households in the region are more likely to be renters. Renter households in the Portland metro area grew by 4.5 percent (26,913 households) between 2011 and 2015, accounting for 95 percent of region's entire household growth. Compared to renter households, homeowner households increased only 0.4 percent during the time period. These new renter households have higher incomes than those who have been renting in the area; however, there remain many low income households with housing cost burdens.

The increase in renter households along the Southwest corridor accounted for 84 percent of total household growth. Focusing on the city of Portland, renter households increased by 10,521 (approximately 10 percent growth), while homeowner households decreased by 378 during the same time period. Similarly to the city of Portland, Tigard experienced decrease in homeowner households, while renter households grew by 11 percent (1,084 households). Even though SW corridor did not experience an absolute decrease in homeowner households, the increase in renter households (2,444 households) in the corridor outstrips the increase in homeowner households (455 households). 
Fig. 3 - Change in household population, 2011-15

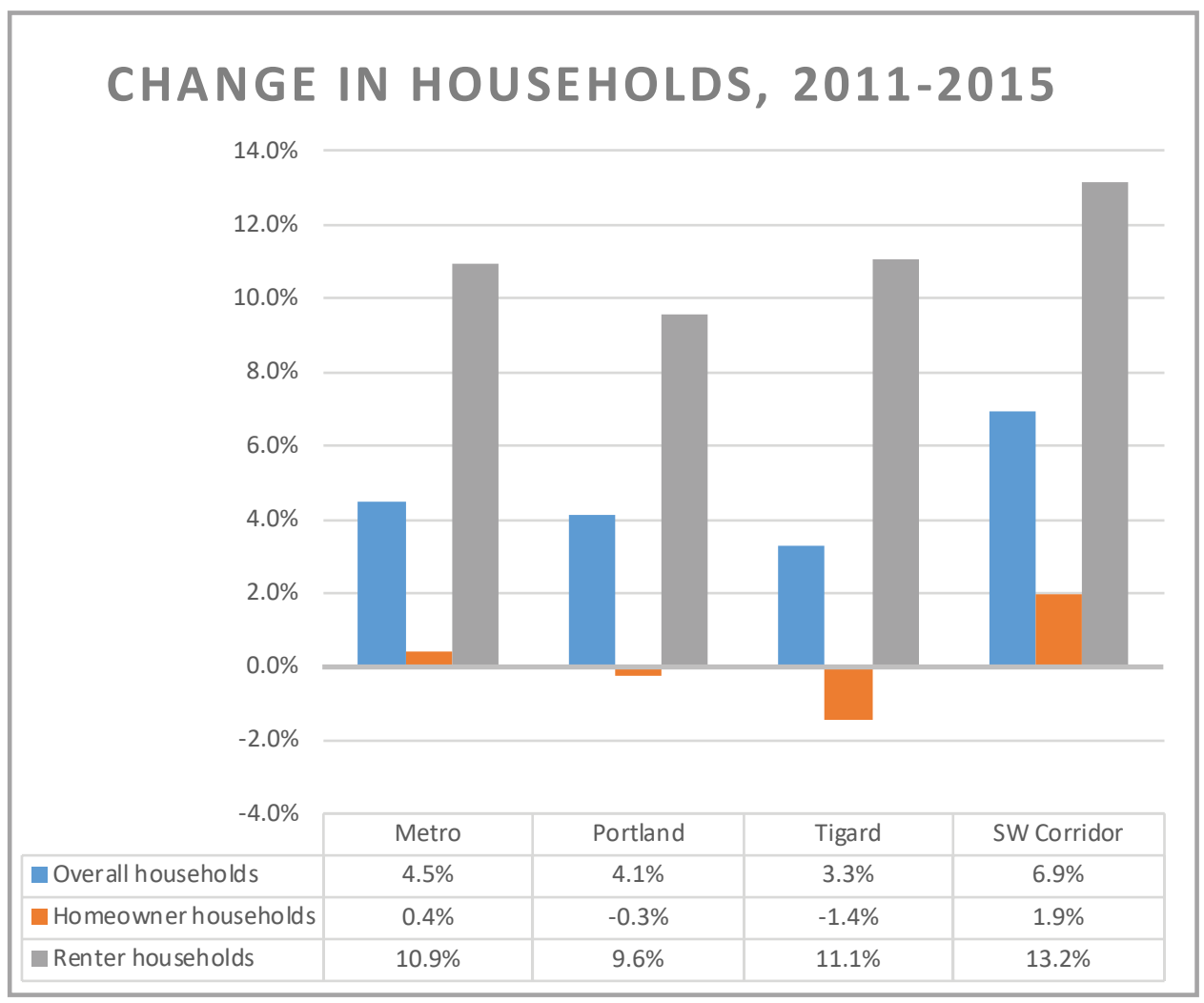

Source: $2011-15$ ACS, 2006-10 ACS

Fig. 4 - Change in renter households by income, 2011-15

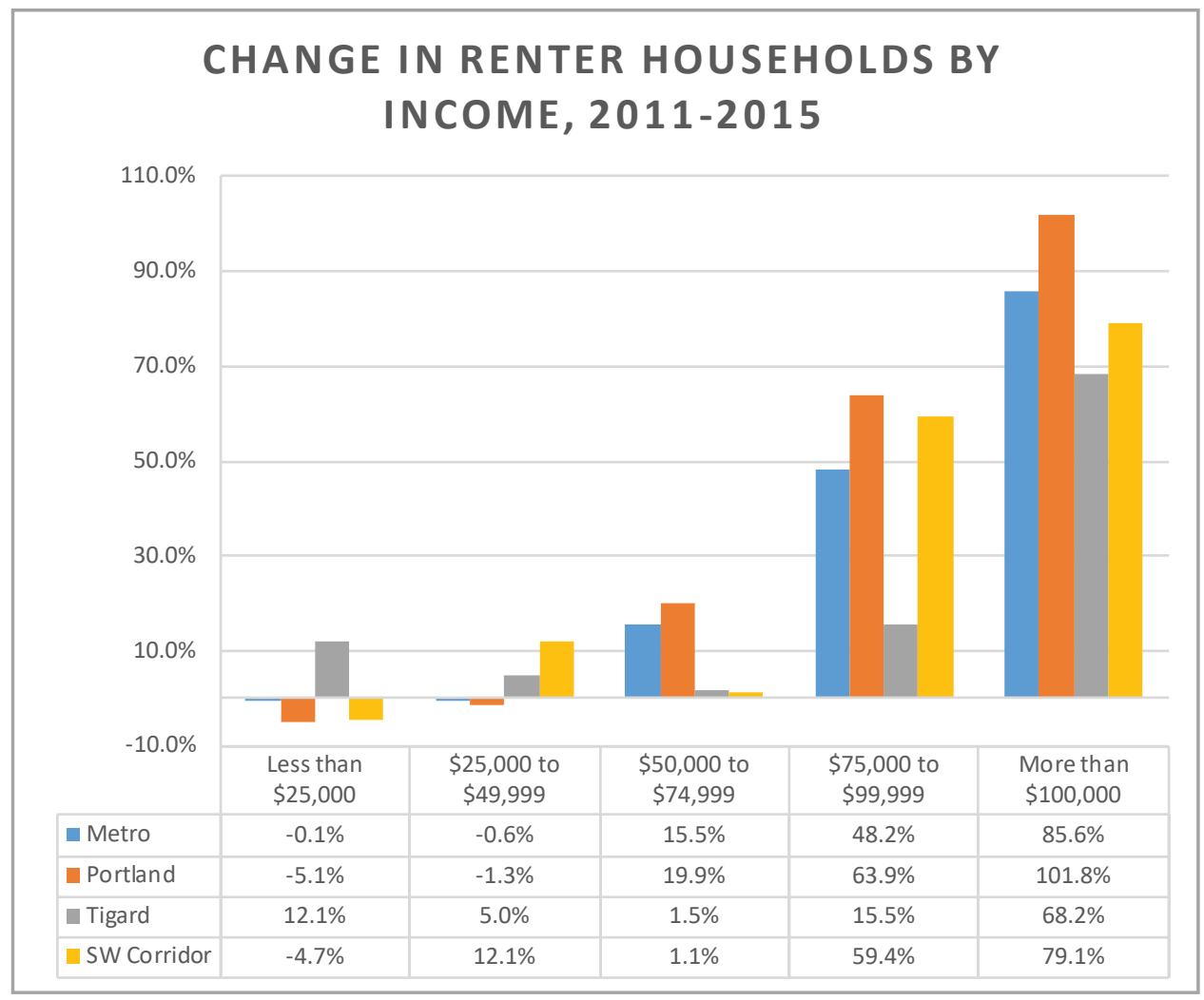

Source: 2011-15 ACS, 2006-10 ACS

In the Portland metro area, new renter households have significantly higher income than the 2017 median income for a family of four in the Portland MSA, $\$ 74,700(P H B, 2017)$. During the last five years, renter households having 
incomes more than $\$ 75,000$ increased by 20,914 households - accounting for 78 percent of renter household growth in metro area. Households having the highest incomes, more than $\$ 100,000$, accounted for 46 percent of all renter household growth. On the other hand, renter households having income less than \$50,000 decreased by 561 households.

Focusing on the city of Portland, the influx of higher income renter households is more significant than the regional trend. The increase in renter households having incomes more than $\$ 75,000$ accounted for 96 percent of the entire renter household growth, while renter households having incomes less than $\$ 50,000$ decreased significantly by 2,855 households. Renter households having incomes around 80 percent of AMI $\$ 50,000$ to $\$ 75,000$ ) grew by 3,238 (almost 20 percent increase during the time period).

The change in renter households in Tigard particularly shows the bifurcation between low income renter households and high income renter households. The increase ( 545 households) in renter households having incomes less than $\$ 50,000$ accounted for 50 percent of Tigard's rental household growth, while the increase in higher income renter households (more than \$75,000) accounted for 47 percent of total growth $(1,084$ households) in rental households., households having incomes around 80 percent AMI increased by only 29 households.

The Southwest corridor itself shows the split of very low and very high income renter households. During the last five years, the Southwest corridor lost 298 very low income renter households (having income less than $\$ 25,000$ ) while very high income renters increased by 1,146 households (47 percent). Similarly to the city of Portland and metro area, 83 percent of entire growth in renter households were made by increase in renter households having incomes more than $\$ 75,000$. Low income renter households $(\$ 25,000$ to $\$ 50,000)$ increased by 673 households, while the increase in households having income between $\$ 50,000$ and $\$ 75,000$ were only 40 households during the time period.

\section{Rental Housing Inventory}

As of May 2017, there are 177,636 rental units in 4,524 buildings in the Portland region. There have been significant numbers of new rental units in multifamily buildings coming online in the Portland metro region and in the Southwest corridor since 2010. It is apparent that new buildings tend to be the more expensive buildings with high quality ratings. These new buildings met the growing demand of the more than three quarters of the growth in renter households that was in households with high incomes. On the other hand, the pre-existing shortage of rental housing for lower income households has not been directly mitigated by these new units of luxury rental housing, where rents are not affordable for incomes at or below 80 percent of area median income. The rental housing inventory, its vacancy rates, and its rental rates are all indicators of the vulnerability of lower income renters. In order to focus on Naturally Occurring Affordable Housing (NOAH), we assess the rental housing inventory based on its quality rating, its age, and its rents. Lower rated buildings and age of building are related; with the obvious correlations to rents.

\section{Rental housing quality: mid-quality dominates the market}

In the Portland metro area, the rental housing units are almost evenly distributed by quality level, represented by CoStar star ratings. We group together the one- and two-star apartments and compare with 3 star apartments. At each geography, the share of one-, two- and three- star apartments in the entire rental inventory accounts for about 70 percent of units.

While new units are high quality, the overall regional stock is dominated by the NOAH type quality level rentals. At all geographies, one, two and thre -star apartment buildings have significant share of apartment buildings (approximately 70 percent), while high quality (four- and star) apartment buildings account for not even 10 percent of the multifamily properties. In particular, Tigard has the lowest number of high quality apartment buildings, and the highest share of 3 star apartment buildings, which have affordability with decent quality for renter households. 
Relatively, the share of high quality apartment (4and5 star) is higher along the Southwest corridor (about 30 percent of entire rental units) - mostly found in the Southwest Waterfront area. However, there are substantial numbers of NOAH type rental buildings in the Southwest corridor. If we consider the two to three star buildings as most susceptible to upscaling, there is the potential for over 11,000 rental units to be regraded in the corridor.

Table 1 - Number of rental housing properties and units by star rating as of 5/11/17

\begin{tabular}{|c|c|c|c|c|}
\hline Star & Metro & Portland & Tigard & SW Corridor \\
\hline & $96(6)$ & $71(4)$ & 0 & 0 \\
\hline & $64,212(3,102)$ & $35,190(1,865)$ & $2,638(85)$ & $5,820(253)$ \\
\hline & $67,284(1,064)$ & $27,723(638)$ & $3,703(36)$ & $5,602(74)$ \\
\hline & $41,823(329)$ & 20,017 (219) & $552(4)$ & $3,079(21)$ \\
\hline & $4,221(23)$ & $3,763(19)$ & 0 & $1,760(5)$ \\
\hline Total & $\begin{array}{c}177,636 \text { units } \\
(4,524 \text { properties })\end{array}$ & $\begin{array}{c}86,764 \text { units } \\
(2,745 \text { properties })\end{array}$ & $\begin{array}{c}\text { 6,893 units } \\
\text { (125 properties) }\end{array}$ & $\begin{array}{c}16,261 \text { units } \\
\text { (353 properties) }\end{array}$ \\
\hline
\end{tabular}

Source: CoStar Multi-Family Property database

Some may perceive the Southwest corridor as a predominantly homeownership and high income area. However, the relative share of rental housing in the corridor is proportionate to the corridor's share of housing in the region. Furthermore, many of these units are not high-end, luxury rentals. The Southwest corridor multifamily rental market represents just over 9 percent of the rental units in the region and under 8 percent of the buildings, meaning the building size is bigger in SW corridor than in the Metro at large.

Fig. 5 - Quality of rental housing inventory: proportion of units by star rating as of 5/11/17

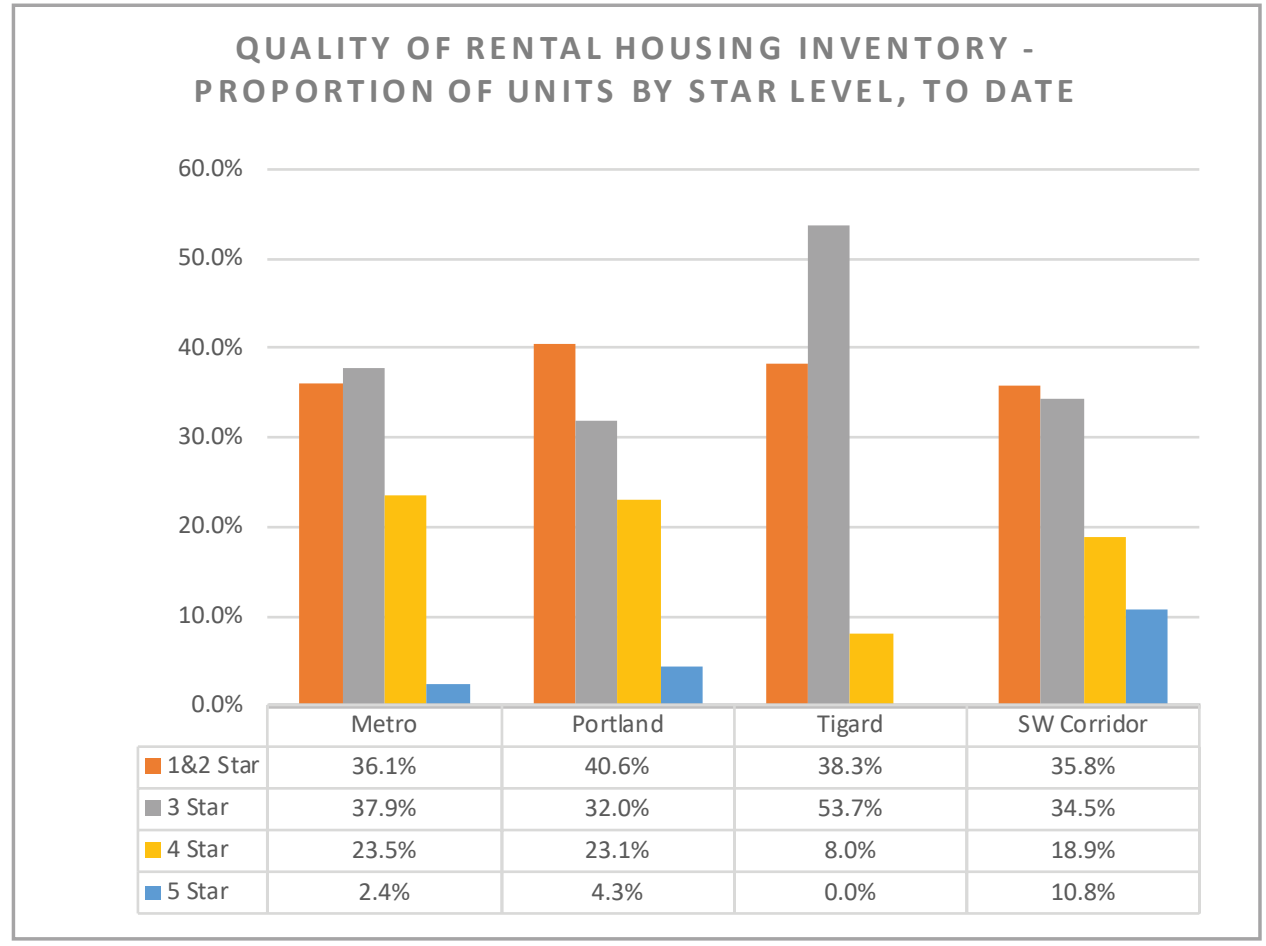

Source: CoStar Multi-Family Property database 


\section{Apartment Vacancy Rate is increasing, for some submarkets}

During the Great Recession years, from 2006 to 2009, the apartment vacancy rate in Portland metro area increased by 6.3 percent. As the market has rebounded, rental vacancies have decreased.

In 2010, the rental vacancy rate dropped below 5 percent, then it has remained around 5 percent. This low vacancy rate indicates the tight rental market in Portland.

Fig. 6 - Apartment vacancy rate, 2006-17, as of 06/22/17

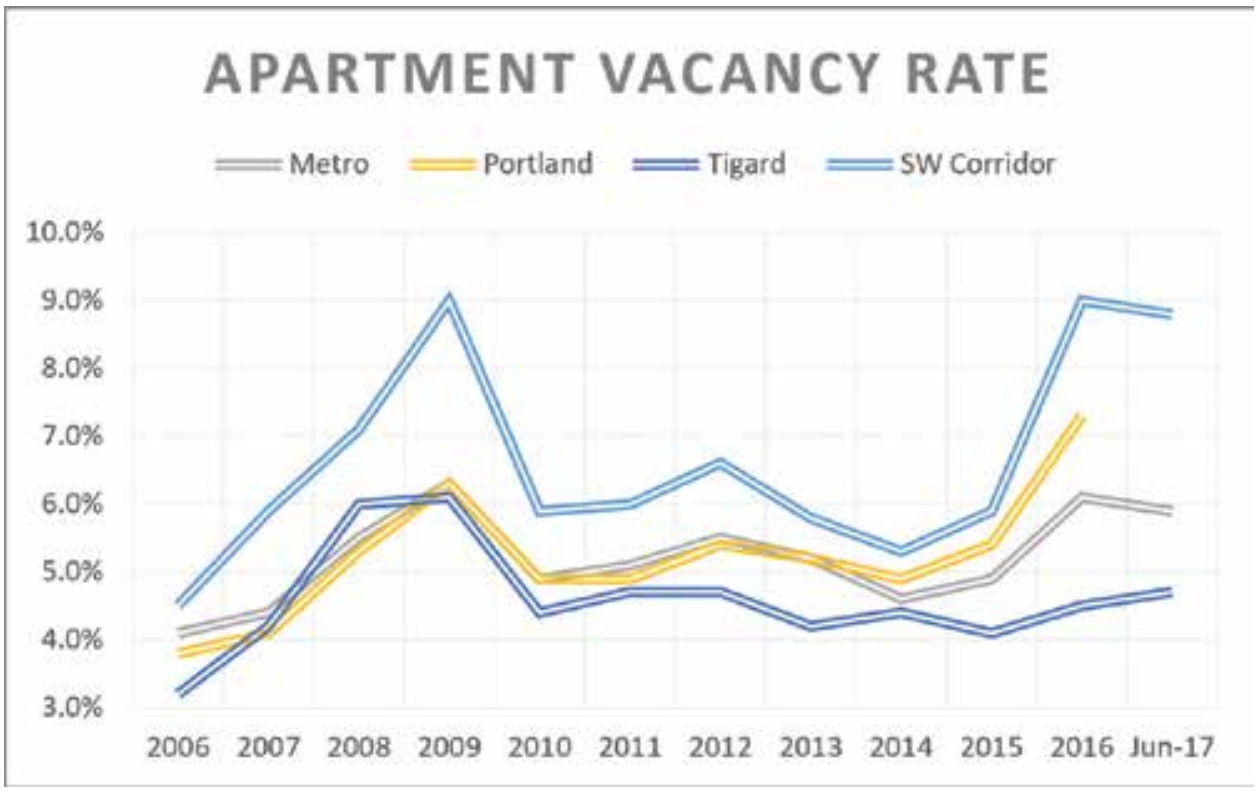

Source: CoStar Multi-Family Property database

Fig. 7 - Occupancy and rental rates in Metro as of 9/12/17

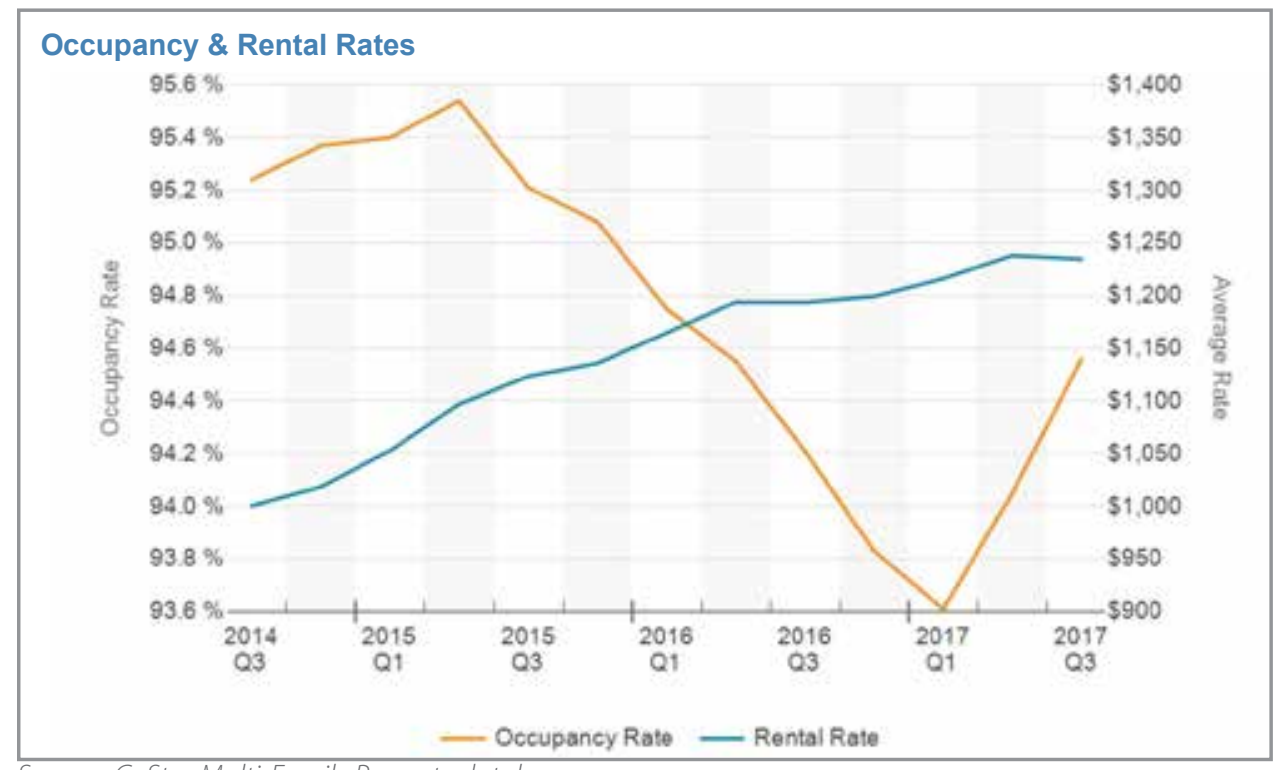

Source: CoStar Multi-Family Property database

The rental vacancy rate in the city of Portland has been similar to regional rate, while that of Tigard has fluctuated more. The rental vacancy rate in Southwest Corridor has always been higher than that of the cities and the metro area.

Vacancies in the Southwest Corridor have increased very recently, as have vacancies metro-wide. The 2016 vacancy rate in SW corridor increased to 9 percent, while city of Portland marked 7.3 percent and Tigard showed 
a 4.5 percent vacancy rate. As of June 2017, the rental vacancy rate is going down slightly compared to 2016, except in Tigard. These increasing vacancies rates relate to the lower occupancy in new, high quality housing, as discussed in the following section.

Fig. 8 - Occupancy and rental rates in SW Corridor as of 9/12/17

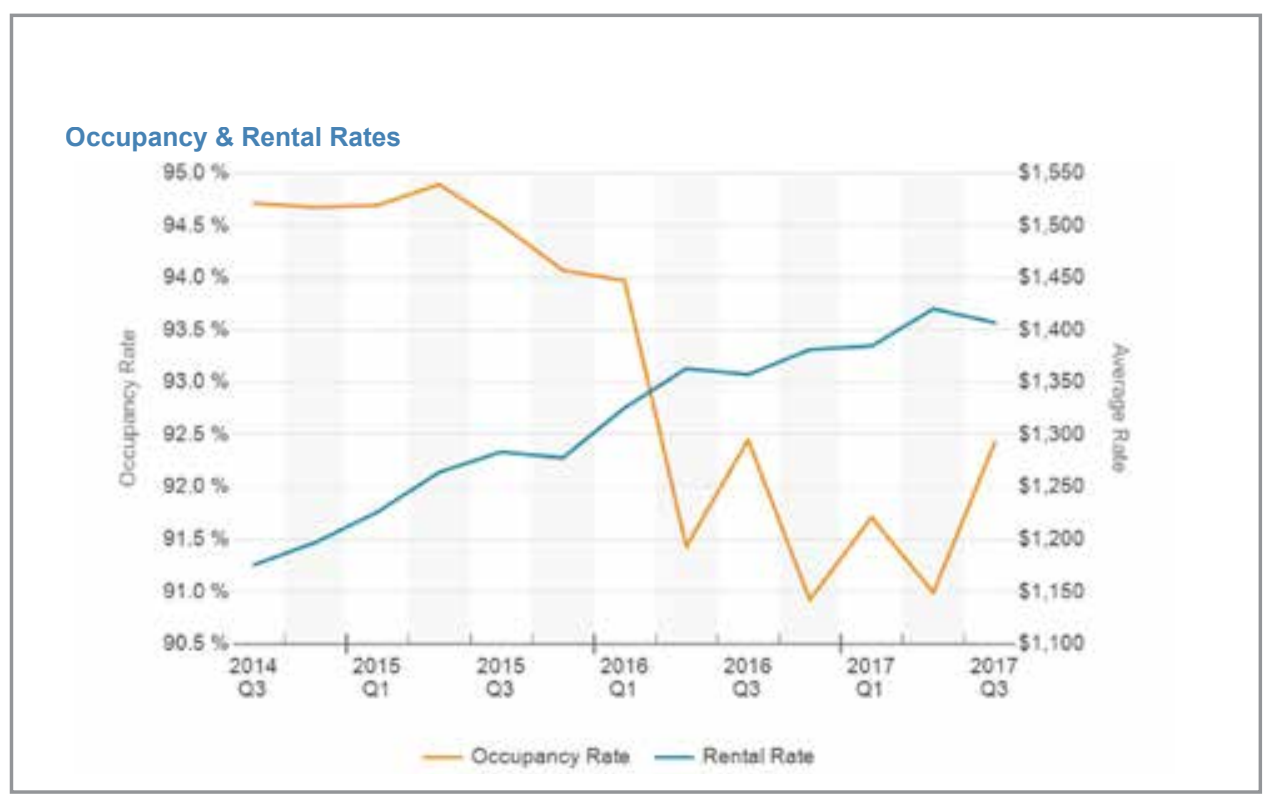

Source: CoStar Multi-Family Property database (Note. This chart is directly generated by CoStar.)

\section{NOAH housing trends differ from high quality housing trends}

The vacancy rate of high quality rental housing is much greater than that of $\mathrm{NOAH}$. The vacancy rate in NOAH shows little fluctuation for a 10 years period, high quality apartments have large changes in vacancy rate. Furthermore, increases in rent has been significant for the decade. Currently, asking rent of high quality apartments is 30 percent more than the rental rate of NOAH regardless of unit size.

Fig. 9 - Vacancy rate and rental rates of NOAH in Metro, as of 08/17/17

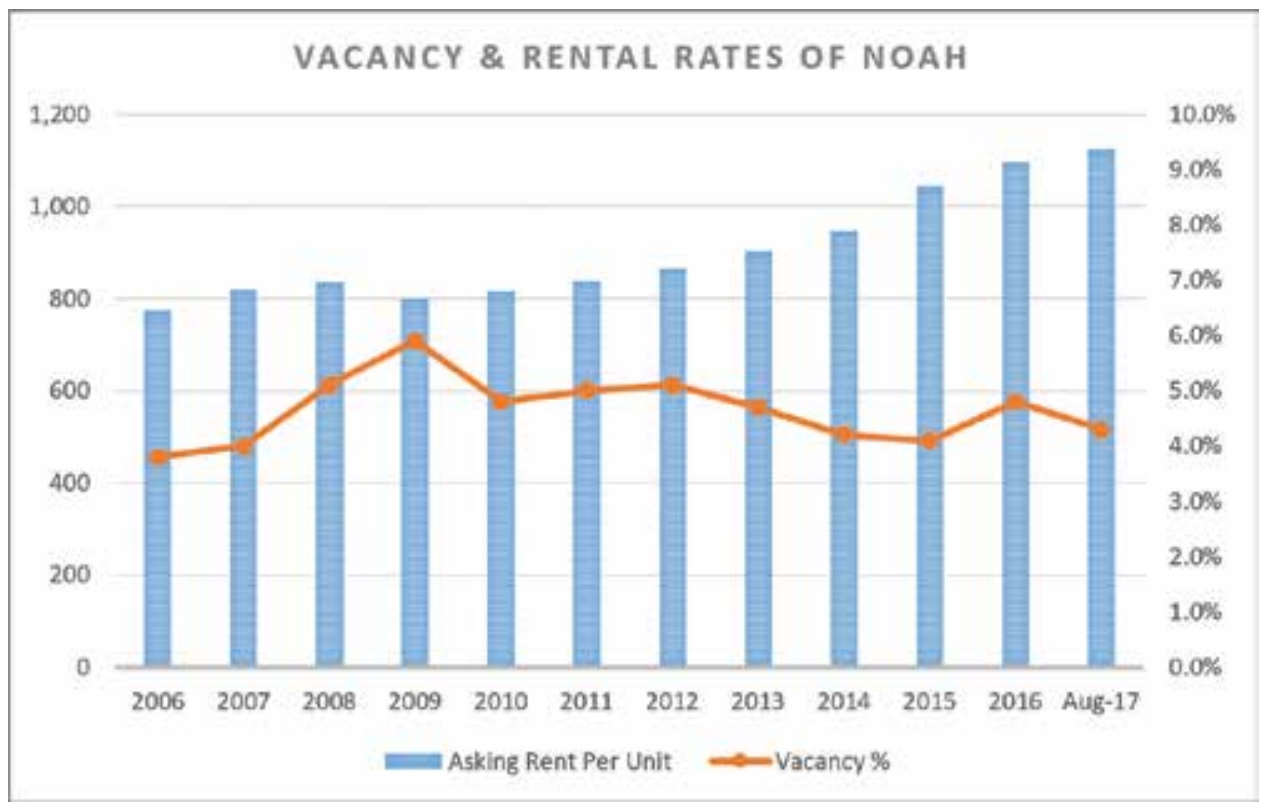

Source: CoStar Multi-Family Property Database 
Fig. 10 - Vacancy rate and rental rates of high quality housing in Metro, as of 08/17/17

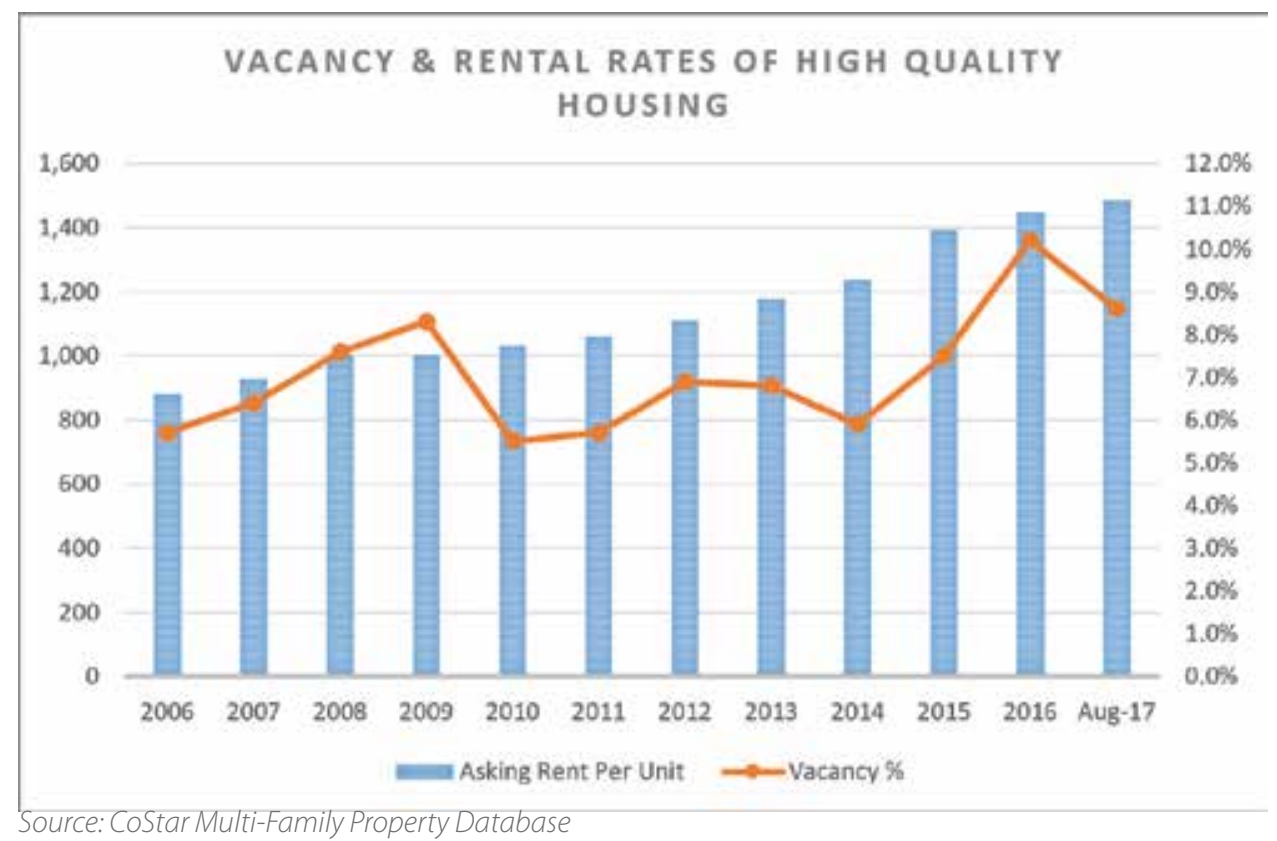

Table 2 - NOAH (1,2,3 stars) and high quality (4,5 stars) housing in Metro, as of 08/17/17

\begin{tabular}{r|c|c} 
& NOAH & High quality \\
Vacancy rate & $4.4 \%$ & $7.8 \%$ \\
\hline Studio asking rent & $\$ 903$ & $\$ 1,229$ \\
\hline 1 bed asking rent & $\$ 1,020$ & $\$ 1,405$ \\
\hline 2 bed asking rent & $\$ 1,198$ & $\$ 1,644$ \\
\hline 3+ bed asking rent & $\$ 1,368$ & $\$ 1,724$ \\
\hline Concessions & $0.9 \%$ & $2.3 \%$ \\
\hline
\end{tabular}

Source: CoStar Multi-Family Property Database (Note. The table was generated by Costar as of 08/17/17.)

Southwest corridor has the highest vacancy rate of high quality housing with the highest asking rent overall, compared within the region. Overall, asking rent of $\mathrm{NOAH}$ at all size units is higher than the region. Regardless of quality, the vacancy rate in the corridor has significantly fluctuated compared to other geographies.

Table 3 - NOAH (1,2,3 stars) and high quality (4,5 stars) housing in SW Corridor, as of 08/17/17

\begin{tabular}{r|c|c} 
& NOAH & High quality \\
Vacancy rate & $6.1 \%$ & $10.2 \%$ \\
\hline Studio asking rent & $\$ 926$ & $\$ 1,344$ \\
\hline 1 bed asking rent & $\$ 1,124$ & $\$ 1,551$ \\
\hline 2 bed asking rent & $\$ 1,348$ & $\$ 2,043$ \\
\hline 3+ bed asking rent & $\$ 1,446$ & $\$ 1,737$ \\
\hline Concessions & $1.5 \%$ & $2.7 \%$ \\
\hline
\end{tabular}

Source: CoStar Multi-Family Property Database Note. The table was generated by Costar as of 08/17/17. 


\section{Rental Affordability}

Rental housing affordability has been a primary concern for the Portland region, prompting declarations of emergency and policy measures to temporarily address rising costs and displacement.

Between 2006 and 2017 (as of 6/22/17), average asking rent has skyrocketed by 56 percent in the Portland metro area. While the city of Portland increase was similar to the regional increase (55 percent), Tigard had the highest rate of rent increase at 60 percent. The SW corridor also had a 59 percent increase in average asking rent due to the significant supply of high-end apartments along the waterfront during the decade.

In order to find the difference of rent increase rate between two time periods, during-recession and afterrecession, the rent increase rate has been separated between 2006-10 and 2010-17. Rent increase during the after-recession shows much higher than the increases over the previous time period (2006-10). After the recession, Portland metro area experienced 43 percent increase in average asking rent, while the rent increase was only 9 percent during the recession.

Rent increases are occurring throughout the Southwest corridor area. Tigard has larger differences in the rent increase between two time periods, since the rent increase rate was only 5 percent during the recession, and then it went up to 53 percent during the time period, 2010 and 2017. On the other hand, Portland and the SW corridor show relatively less differences of rent increase rates between two time periods than the region and Tigard. Portland shows 27 percent differences between the rent increase rate of the two time periods and the SW corridor had a 20 percent of difference in rent increase.

Fig. 11 - Average asking rent per unit, 2006-17 as of 06/22/17

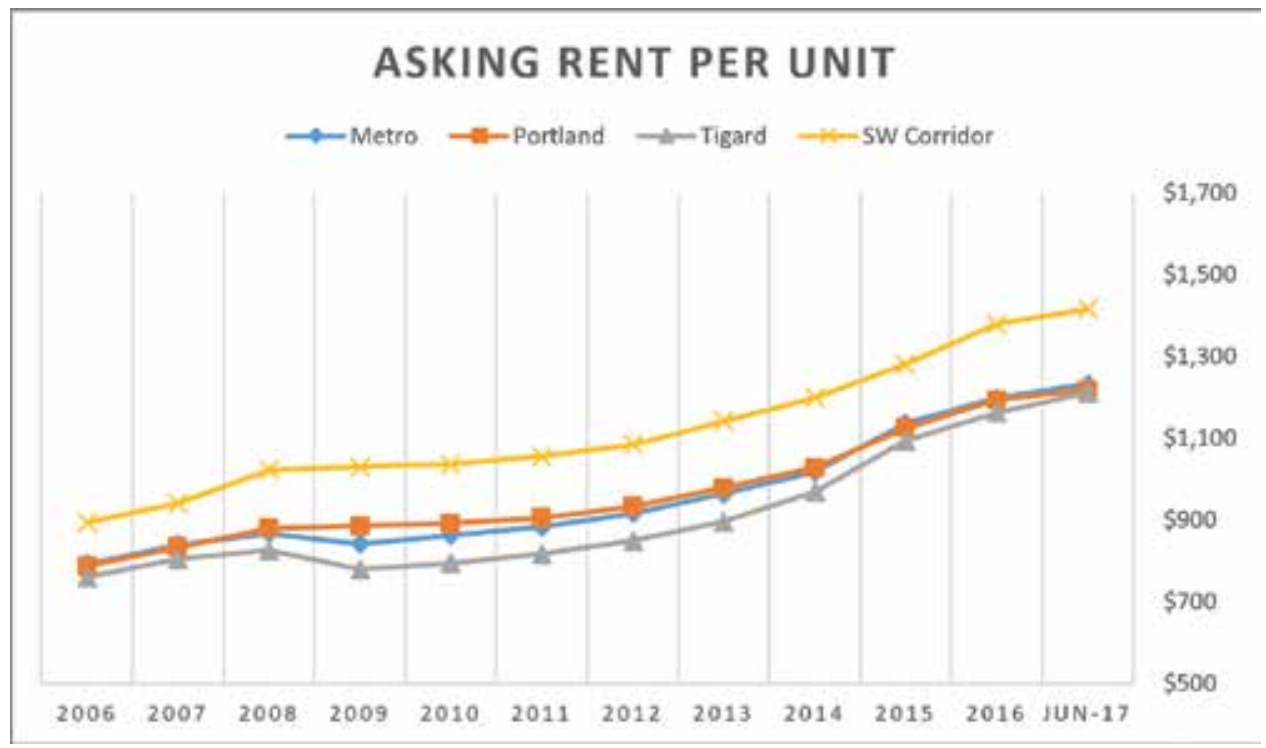

Source: CoStar Multi-Family Property database 


\section{Average asking rent by star rating}

Dicing the average rent increase by star rating, high-end apartments ( 4 and 5 star) brought the highest rent increase during the last decade in the metro area. Regionally, an almost 71 percent rent increase occurred to high quality apartments during the last decade, while low quality apartments ( 1 and 2 star) have experienced a 39 percent rent increase. In particular, 3 star apartments in the city of Portland experienced the lowest rent increase, 31 percent. While the rent increases for lower quality units have not been as sharp as those for the high end of the market, given the relative flatness of incomes and the level of housing cost burden for lower-income households, these increases are creating a serious affordability crisis.

Fig. 12 - Asking rent per unit by star rating in Metro, 2006-17 as of 6/22/17

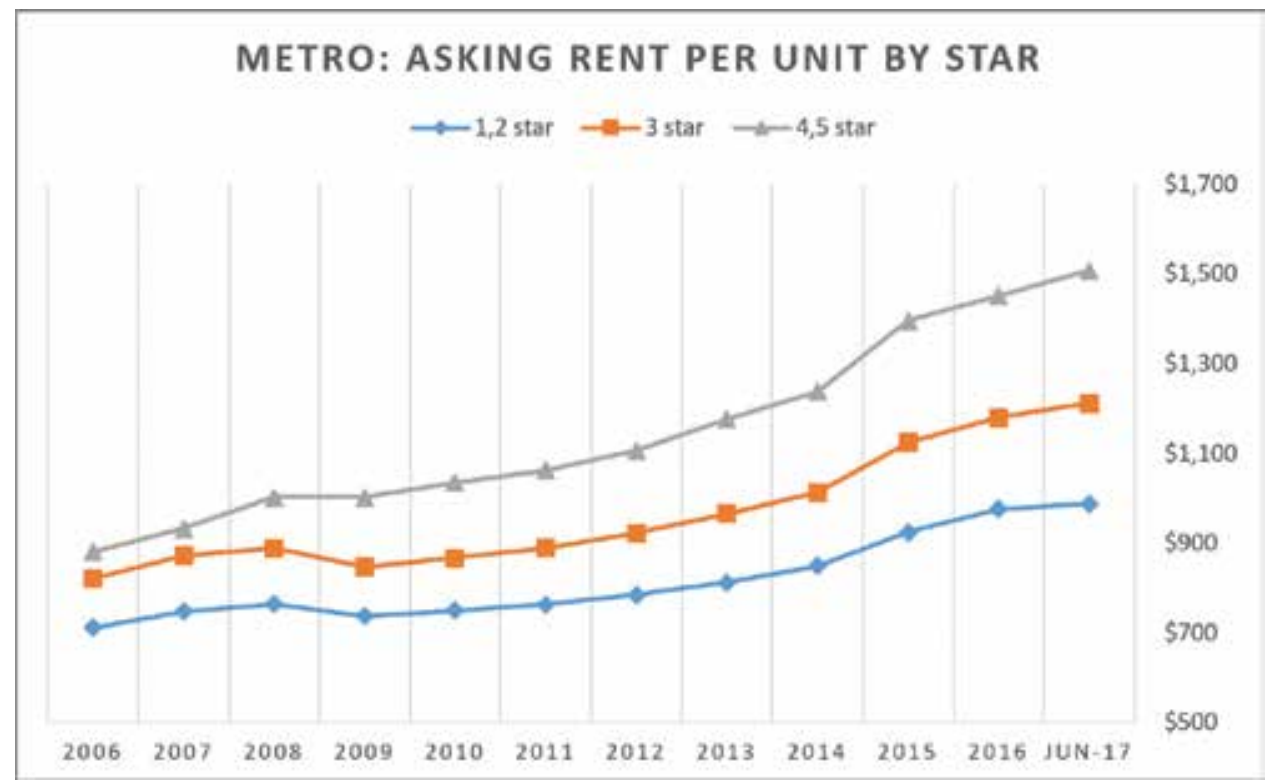

Source: CoStar Multi-Family Property database

Fig. 13 - Asking rent per unit by star rating in Portland, 2006-17 as of 6/22/17

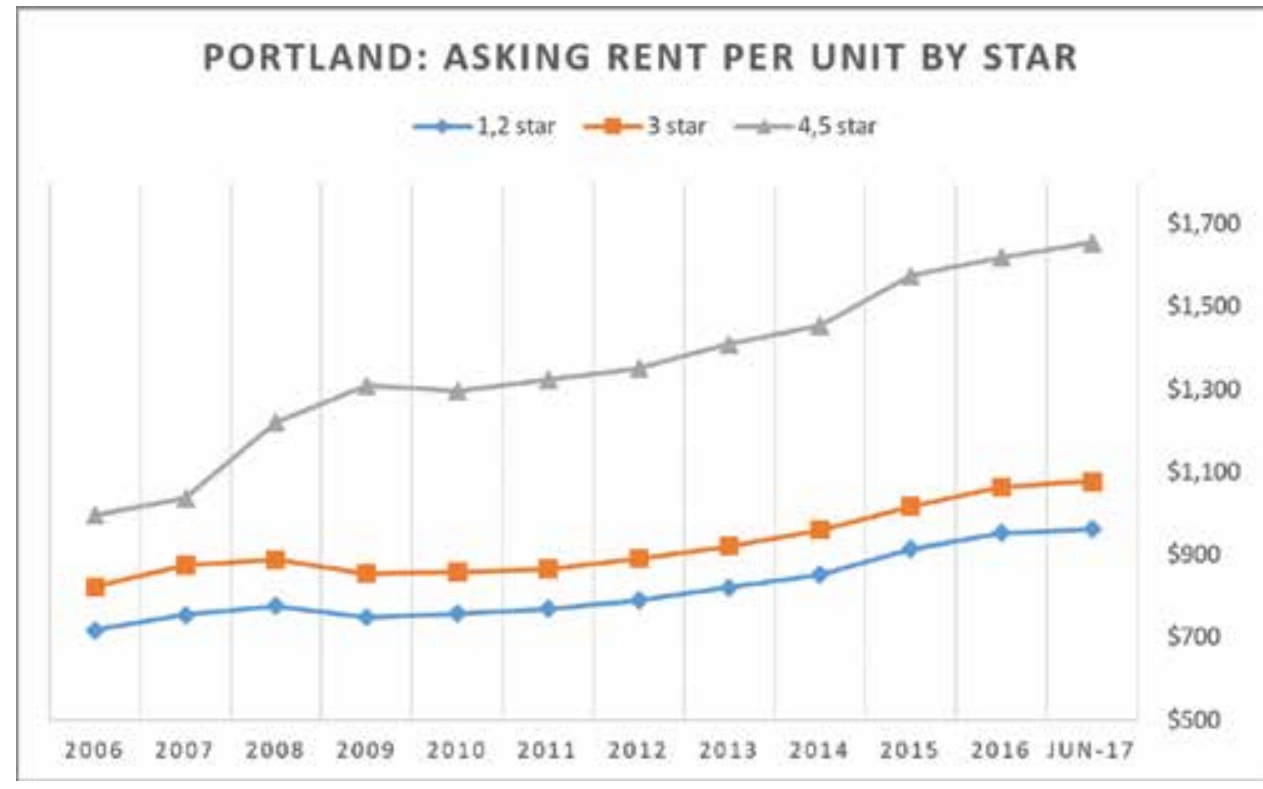

Source: CoStar Multi-Family Property database 
Fig. 14 - Asking rent per unit by star rating in Tigard, 2006-17 as of 6/22/17

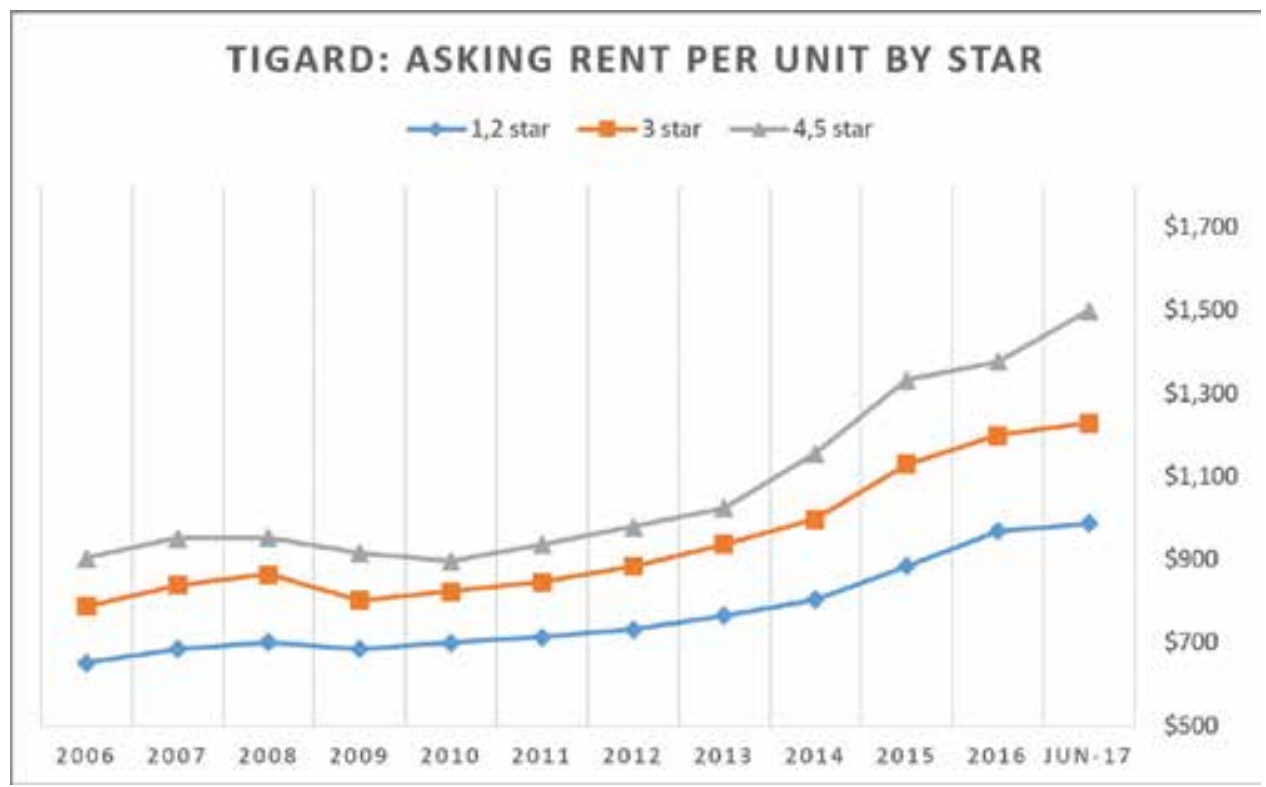

Source: CoStar Multi-Family Property database

Fig. 15 - Asking rent per unit by star rating in SW Corridor, 2006-17 as of 6/22/17

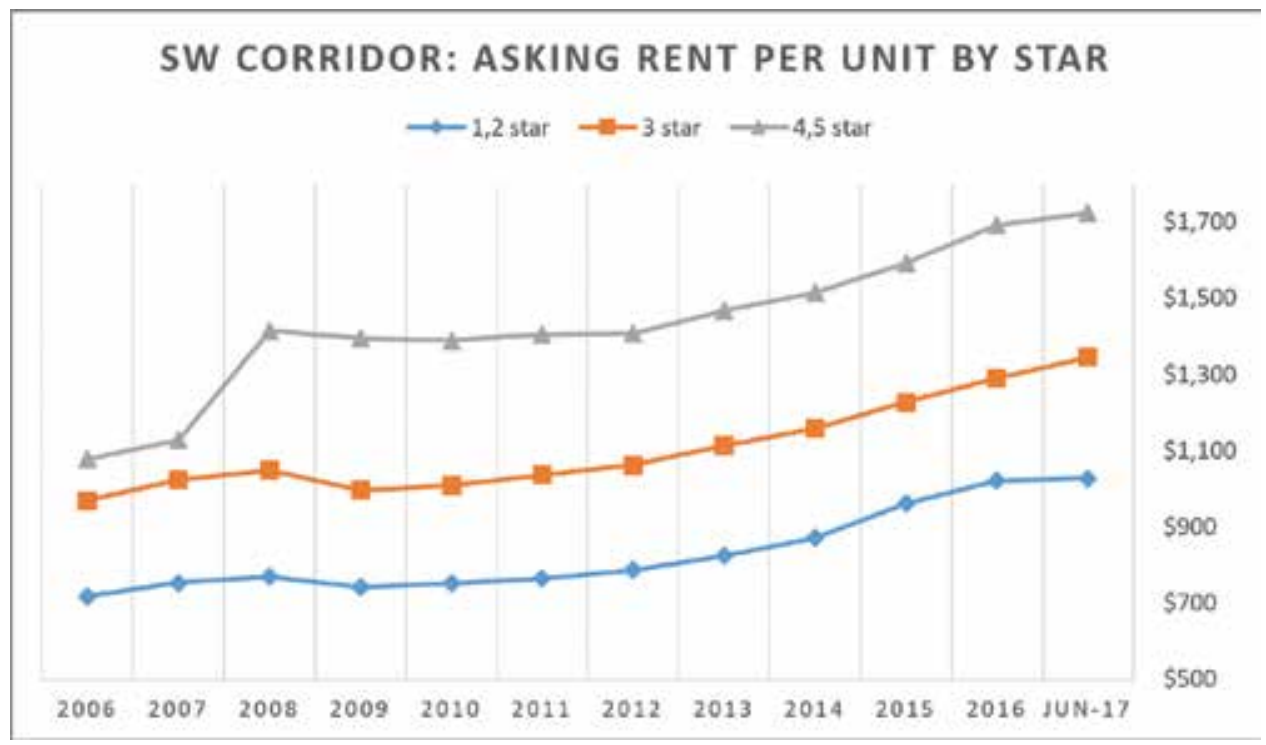

Source: CoStar Multi-Family Property database

The affordability of what is currently considered NOAH is already under pressure by the overall trends in the market. This housing is precarious - in that its conversion would displace tenants who are likely to have a difficult time finding units in the current rental market. In the next section of the report, we consider the geography of $\mathrm{NOAH}$ housing to better understand the spatial dimensions of this market. 


\section{The geography of NOAH in the Portland region}

Naturally occurring affordable housing, the lower quality units on the market, exists throughout the metropolitan area, including in areas that are perceived as high income and high opportunity and areas currently planning for transit line expansion. NOAH rental buildings are also located in areas that are racially diverse and lower income, where renters are particularly vulnerable to displacement pressures.

As of May 2017, a total 131,592 units (4,172 properties) of naturally occurring affordable housing exist in Portland metro area. Over half of these units are in the City of Portland itself.

NOAH located in Multnomah County account for 63 percent of the county's units. Clackamas County has 10 percent of units in low quality apartments and Washington County has 27 percent of its stock of NOAH units.

Fig. 16 - Map of NOAH (1,2,3 star apartments) in Metro as of 05/11/17

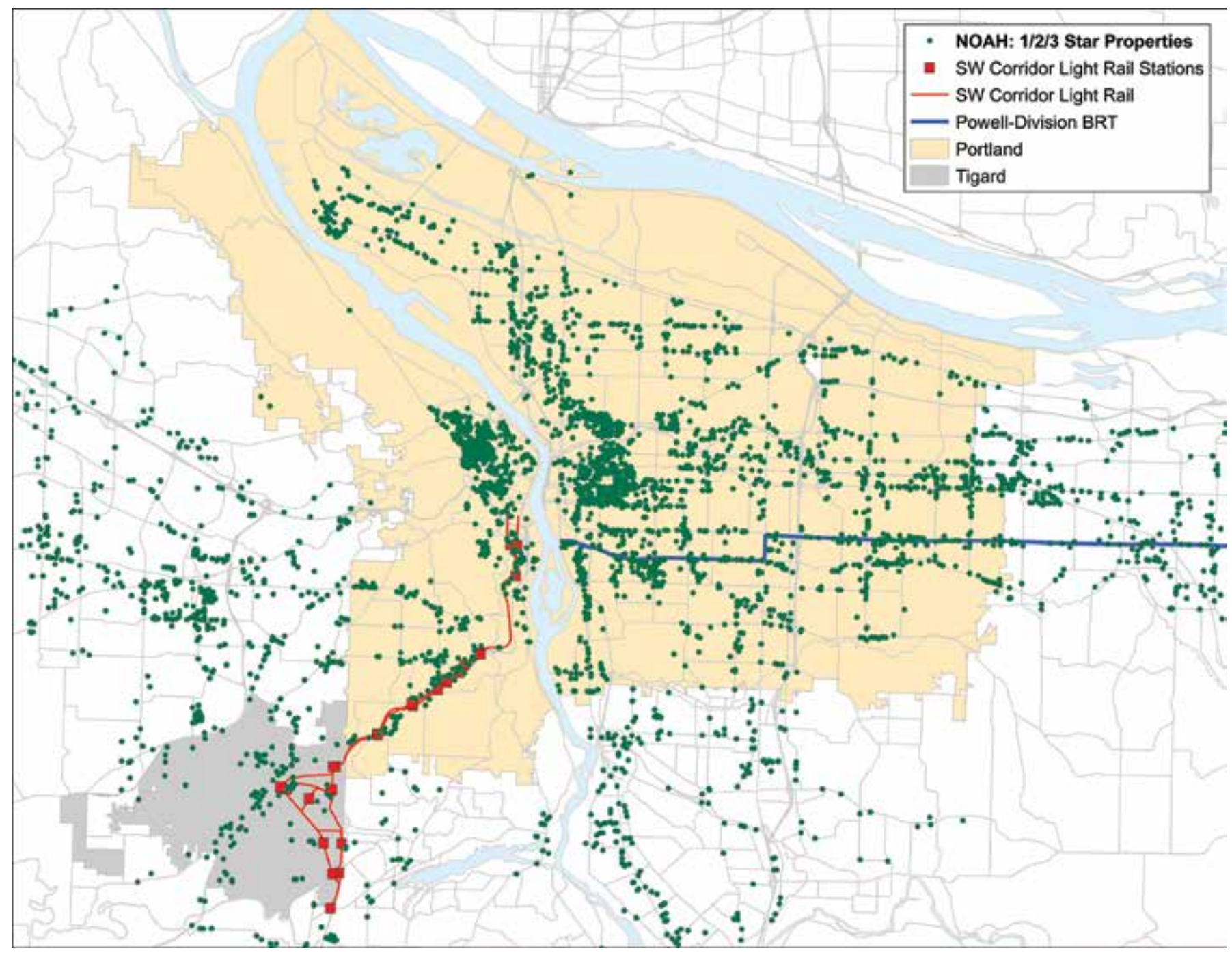

Source: CoStar Multi-Family Property database 


\section{Is NOAH in jeopardy in the region?}

When Naturally Occurring Affordable Housing is sold to new owners and investors, it is often because of the opportunity for up-scaling the property and returning much higher rents. Sales of multifamily properties can indicate that investment activity is imminent. The result is immediate for current tenants who either cannot remain during remodeling or who can't afford increased rents; and in the long term as the loss of affordable housing from the market altogether. In the sale of a multifamily building, many households may be displaced at once.

While the recession slowed sales until 2009, transactions of apartment properties in the Portland region have revived after 2010. Increased sales in gentrifying neighborhoods and areas of new public investment (including in transit) are most likely to be susceptible to up-scaling as returns are greatest. This analysis considers the pace and price of apartment sales, as well as their locations, to understand the vulnerabilities in this segment of the market.

\section{Sales trends: $2006-17$}

\section{Number of buildings and units sold per year}

In the metro area, 2,285 apartment properties were sold during the last decade — some 92,000 units transacted from 2006 to 2017, some more than once. The great majority of these sales, over 70 percent, have occurred since 2010.

The units sold can exceed the number of units existing since the number of units sold in this report refers to the accumulated units sold during the period. Since some properties were sold repeatedly during the time period, number of units sold herein was calculated by adding up all units sold for the time period.

Fig. 17 - Number of rental housing properties and units sold per year in Metro, 2006-17 as of $8 / 10 / 17$

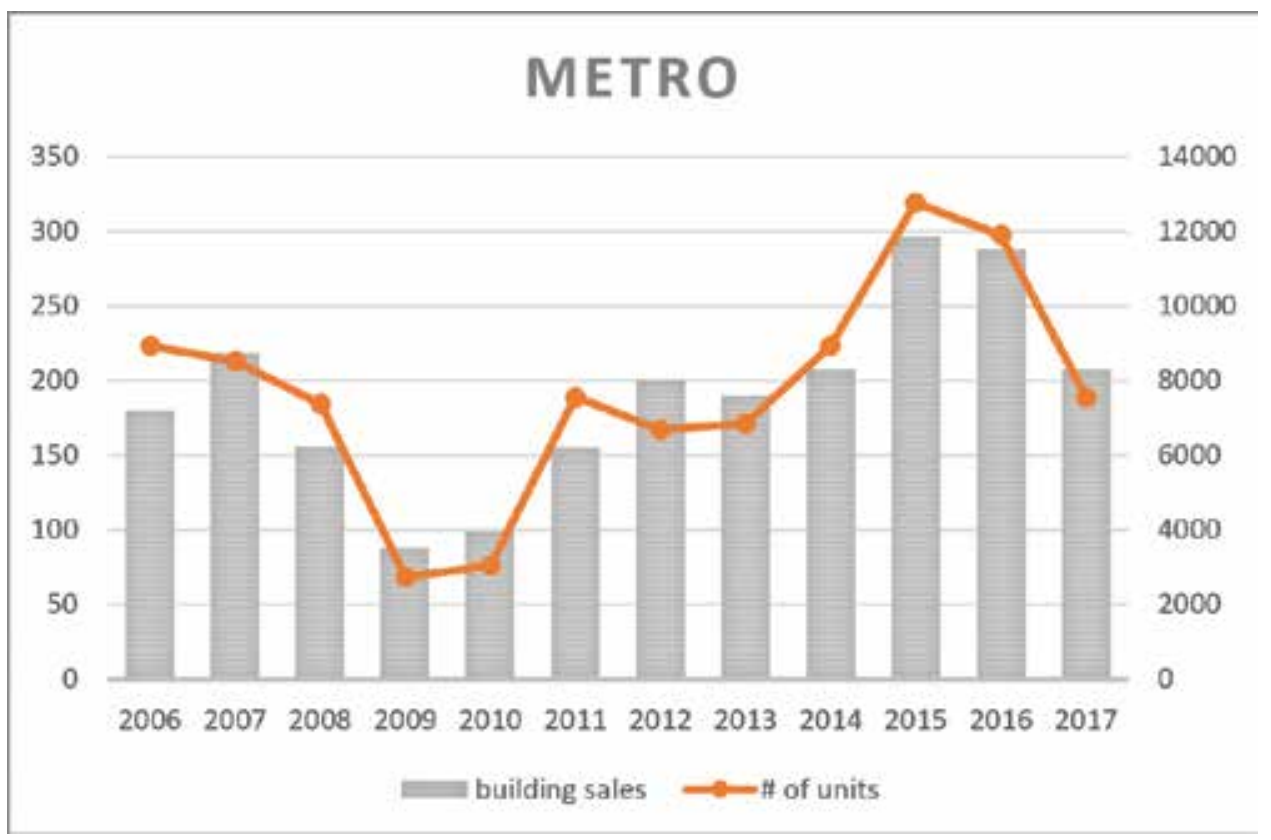

Source: CoStar Sales COMPS database 
Table 4 - Average number of rental housing properties and units sold per year, 2010-17, as of $8 / 10 / 17$

\begin{tabular}{r|c|c} 
& $\begin{array}{c}\text { Average properties } \\
\text { sold per year }\end{array}$ & $\begin{array}{c}\text { Average units } \\
\text { sold per sale }\end{array}$ \\
\hline Metro & 205 & 40 \\
\hline Portland & 132 & 26 \\
\hline Tigard & 4 & 52 \\
\hline SW Corridor & 15 & 32 \\
\hline
\end{tabular}

Source: CoStar Sales COMPS database

From 2010 to 2017, many cities in metro area have seen the multifamily market become very active. In fact, compared to the city of Portland, most suburban communities experienced sales of significant portions of their rental stock during the time period. Gresham, Beaverton, and Hillsboro all experienced significant sales in apartments, with 40 to 50 percent of all units selling during the time period.

Table 5 - Sales percentage for the top 10 cities with the largest share of the region's rental units, 20102017

\begin{tabular}{r|r|r|c|c}
\multicolumn{1}{r}{ City } & Sales & Units sold & Units overall & $\begin{array}{c}\text { Percent of all rental } \\
\text { units in jurisdiction }\end{array}$ \\
\hline Portland & 1,054 & 27,696 & 86,764 & $31.9 \%$ \\
\hline Gresham & 134 & 5,660 & 22,988 & $42.9 \%$ \\
\hline Beaverton & 125 & 10,621 & 13,202 & $46.2 \%$ \\
\hline Hillsboro & 56 & 6,157 & 12,729 & $48.4 \%$ \\
\hline Milwaukie & 46 & 1,579 & 7,392 & $21.4 \%$ \\
\hline Tigard & 32 & 1,649 & 6,893 & $23.9 \%$ \\
\hline Oregon City & 24 & 1,057 & 2,610 & $40.5 \%$ \\
\hline Tualatin & 21 & 2,405 & 4,044 & $59.5 \%$ \\
\hline Lake Oswego & 20 & 790 & 2,785 & $28.4 \%$ \\
\hline Wilsonville & 18 & 3,611 & 3,150 & $114.6 \%$ \\
\hline
\end{tabular}

Source: CoStar Sales COMPS database

The average number of units sold in each transaction provides a sense of the building types that are on the market. For example, in Hillsboro and Tualatin the properties sold were larger buildings, with over 100 units sold on average per transaction. Wilsonville shows the highest percentage of units sold to all rental units in the city with the average of 201 units per sale; 115 percent can be interpreted as repeated sales between 2010 and 2017. Three properties having fairly large units in Wilsonville went through repeated transactions. For example, a single rental property having 274 units has been transacted three times between 2012 and 2016.

These data show that suburban communities can be more vulnerable to apartment sales and conversion because the apartment sales affect significant proportions of their community's overall rental housing stock. 


\section{Southwest Corridor}

Along the Southwest corridor, multifamily property sales have been increasing through 2017. Sales of 119 multifamily properties occurred over the past decade, with 73 percent of total units sold along the corridor. The market has gotten especially hot in the last three years, when 34 percent of the decade's apartment sales have occurred.

Fig. 18 - Number of rental housing properties and units sold per year in SW Corridor, 2006-2017, as of 8/10/17

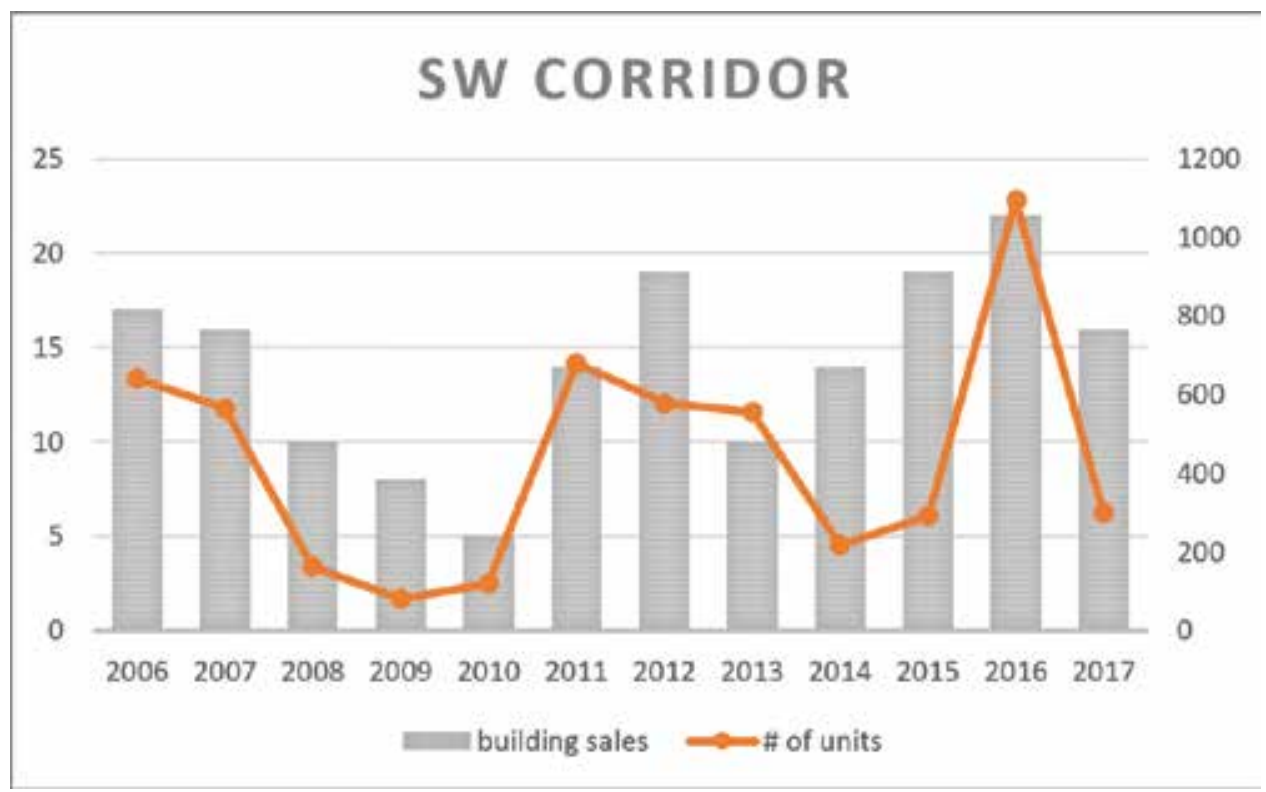

Source: CoStar Sales COMPS database

However, sales activity is not even throughout the corridor. Tigard in particular has seen decreasing sales activity, and generally has had more variance from year to year in the market.

Fig. 19 - Number of rental housing properties and units sold per year in Portland, 2006-2017, as of $8 / 10 / 17$

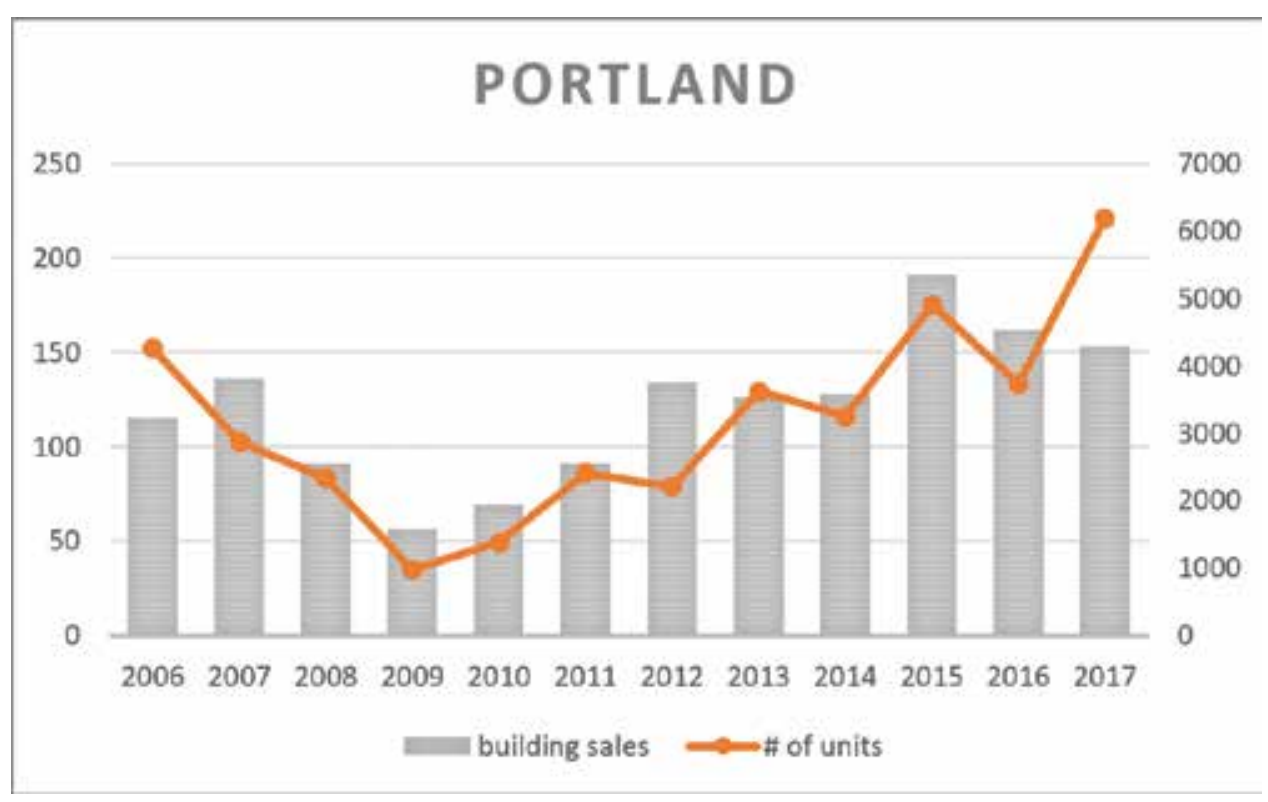

Source: CoStar Sales COMPS database 
Fig. 20 - Number of rental housing properties and units sold per year in Tigard, 2006-2017, as of $8 / 11 / 17$

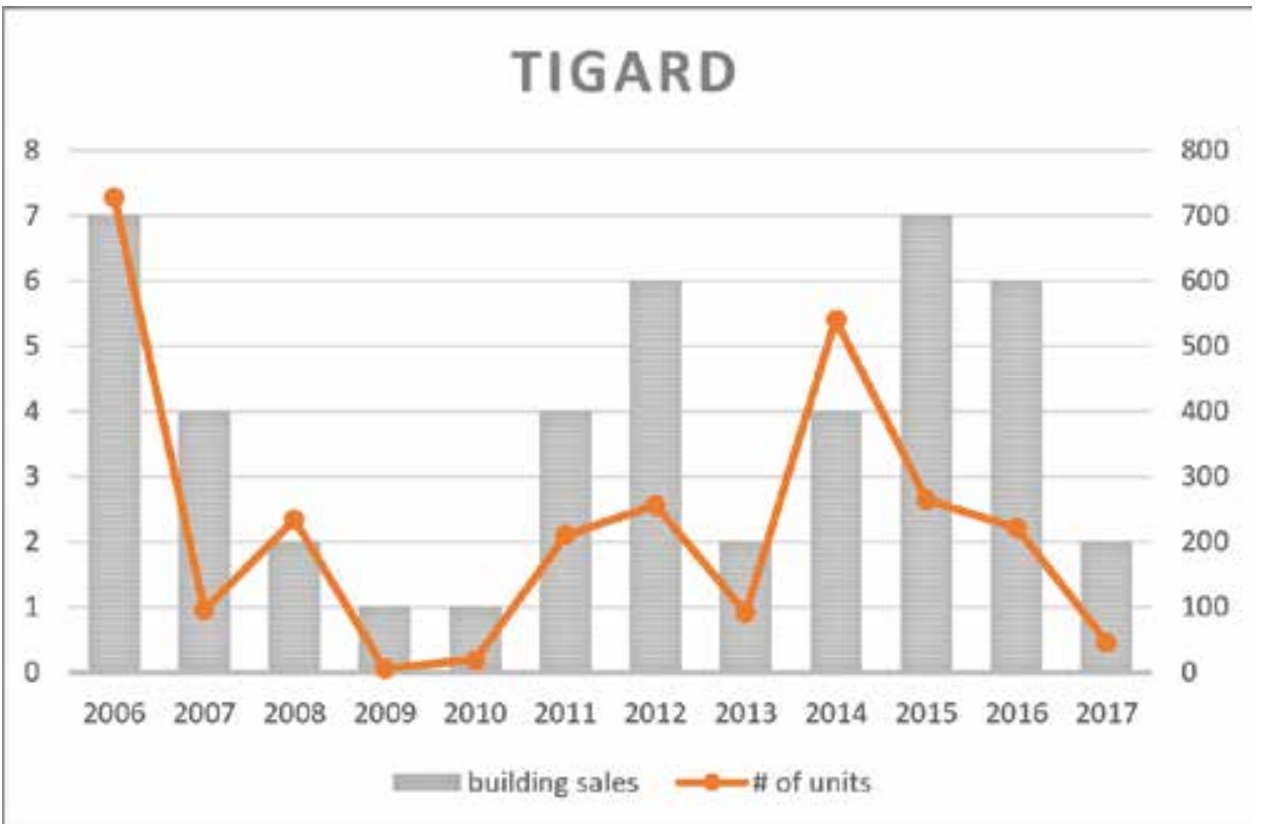

Source: CoStar Sales COMPS database

\section{Sales by quality of rental housing: NOAH on the market}

When dicing the sales of apartment buildings during the last decade in the metro area, 91 percent of total building sales were in NOAH, accounting for 74 percent of the units sold.

Table 6 - Number of units and properties sold by star rating between 2006 and 2017, as of 8/10/17

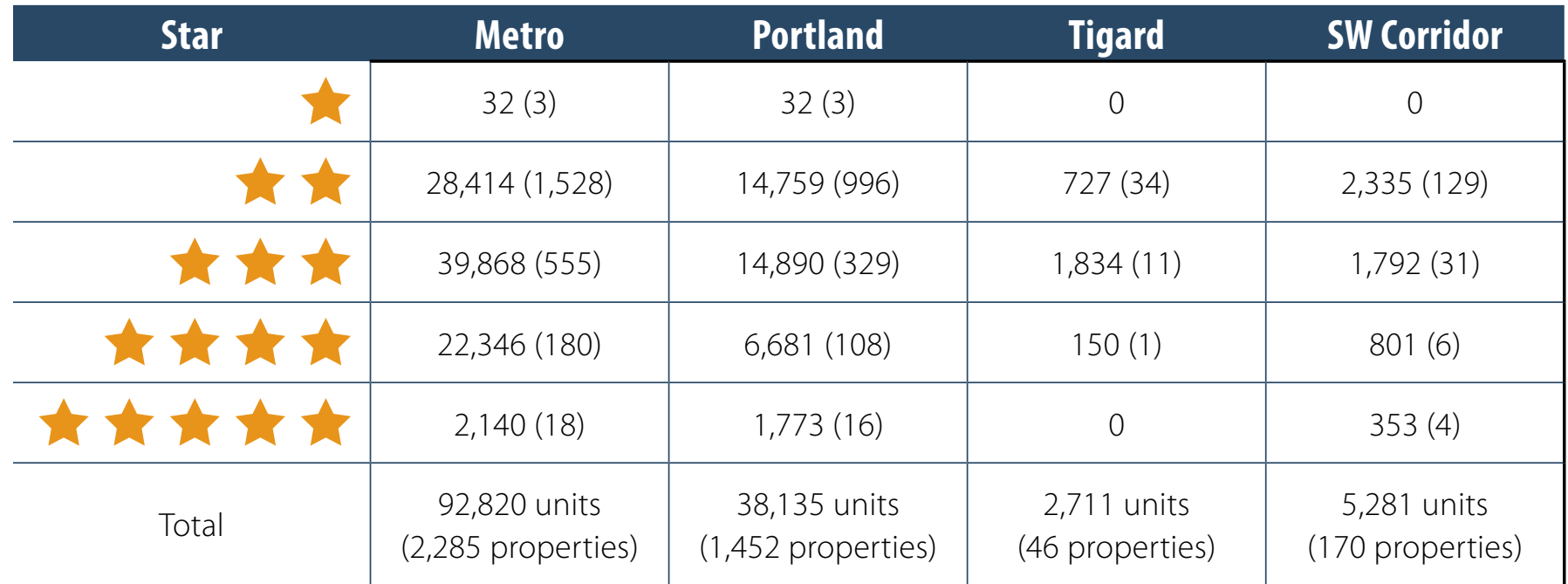

Source: CoStar Multi-Family Property database

Along the SW Corridor, 160 transactions of NOAH for the last decade accounted for 78 percent of total units sold. 


\section{Rising price of rent and per-unit apartment sales, 2010-17 (as of 8/10/17)}

As market rents increase, converting $\mathrm{NOAH}$ to higher grade housing can be more profitable. In turn, as the price per unit increases, it becomes necessary for new buyers to increase rents in order to make a return on the purchase. During the last seven years, the average per-unit sale price grew by 78 percent in Portland metro area, while average asking rent grew by 43 percent.

Fig. 21 - Change in rent and per-unit sale price in Metro, 2010-2017, as of 8/10/17

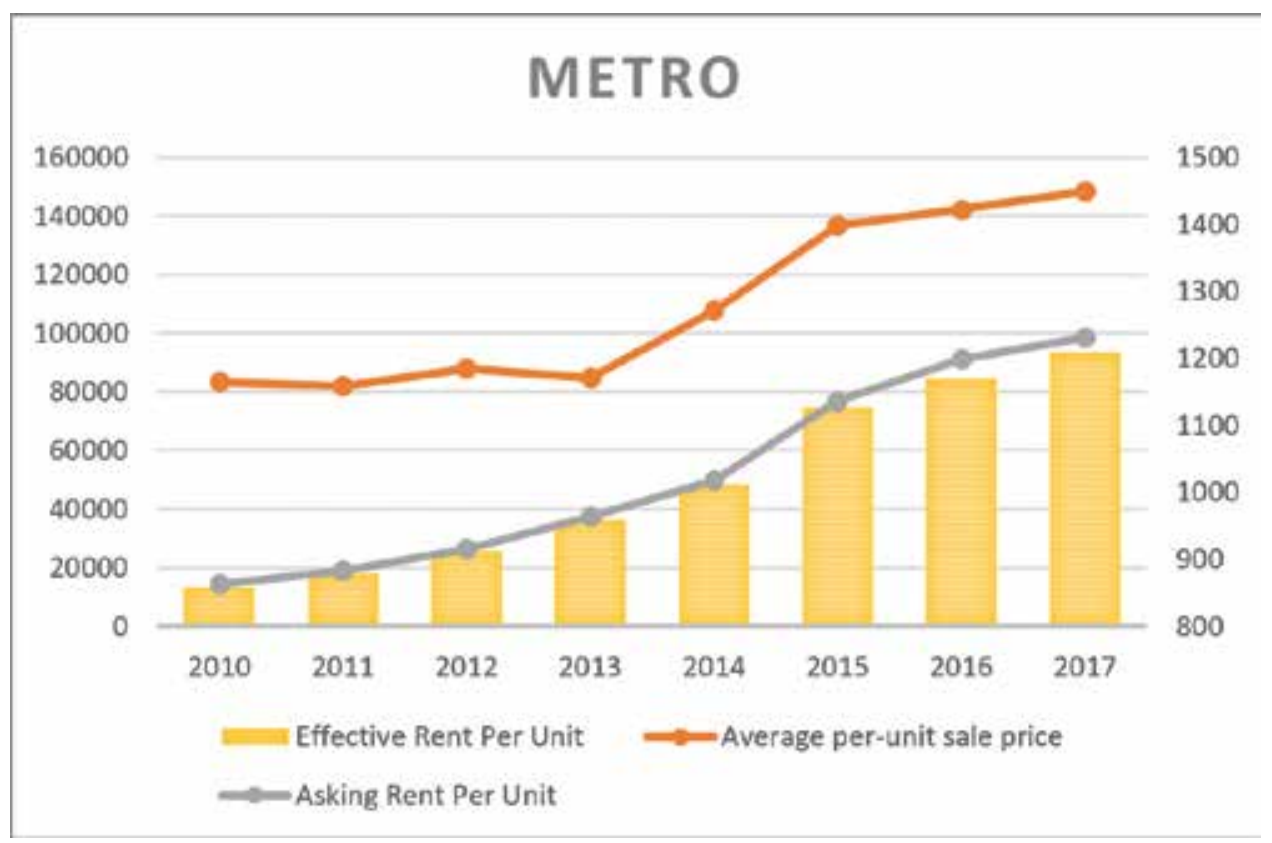

Source: CoStar Sales COMPS database

The city of Portland had a lower rate of increase (63 percent) in per-unit sale price, but the average sales prices in Tigard and along the Southwest corridor skyrocketed. Between 2010 and 2017, sale price per unit in Tigard jumped up to $\$ 131,912$ from $\$ 54,000$, showing 144 percent increase. The significant increase in price per unit of Tigard is significant since all but one of the apartment sales in Tigard were made to two and three star rental properties. The remarkable growth of sale price per unit is attributable to sales in $\mathrm{NOAH}$.

Even more, SW corridor marked 274 percent increase in sale price per unit, starting at $\$ 54,682$ in 2010 to $\$ 204,584$ in August 2017. The huge growth of price per unit along the corridor at large is influenced recent transactions of the highest quality rental housing in Southwest waterfront. 
Fig. 22 - Change in rent and per-unit sale price in Portland, 2010-17, as of 8/10/17

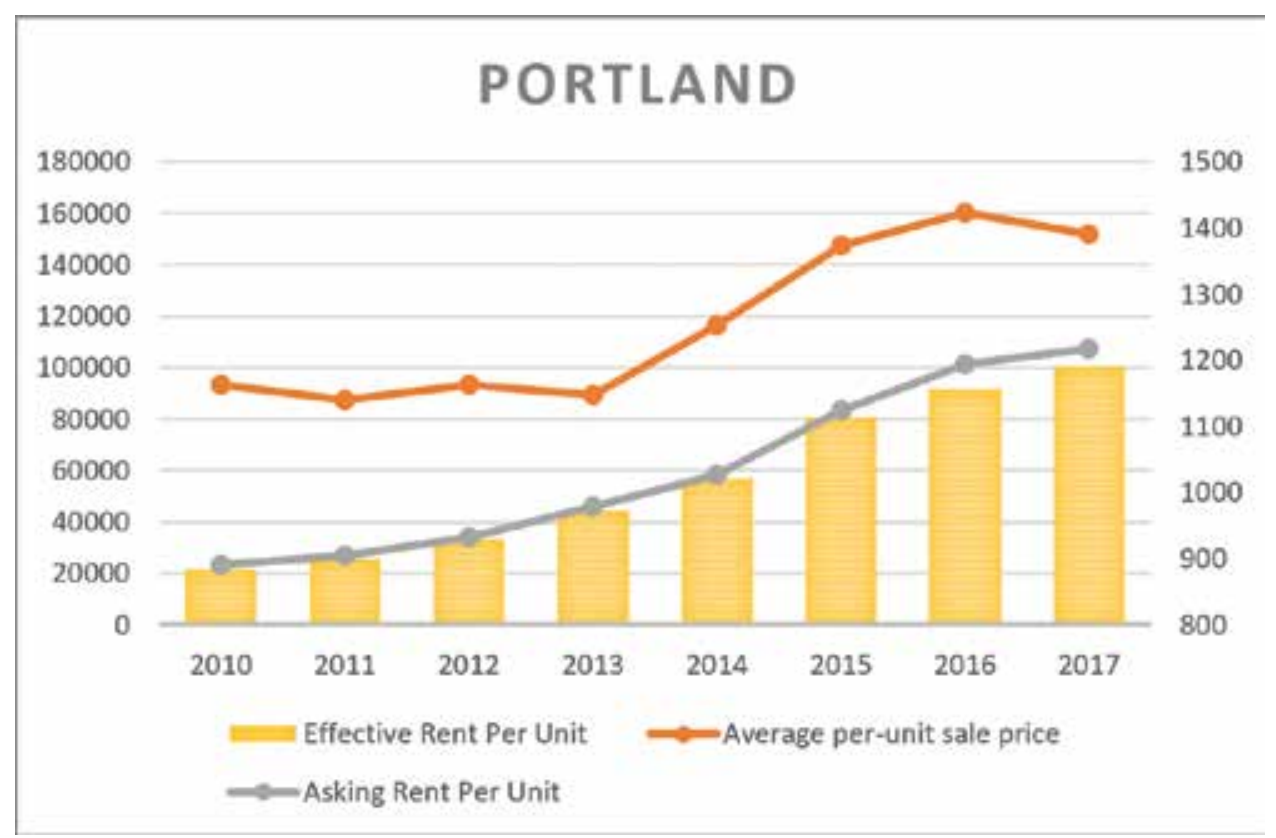

Source: CoStar Sales COMPS database

Fig. 23 - Change in rent and per-unit sale price in Tigard, $2010-17$, as of 8/10/17

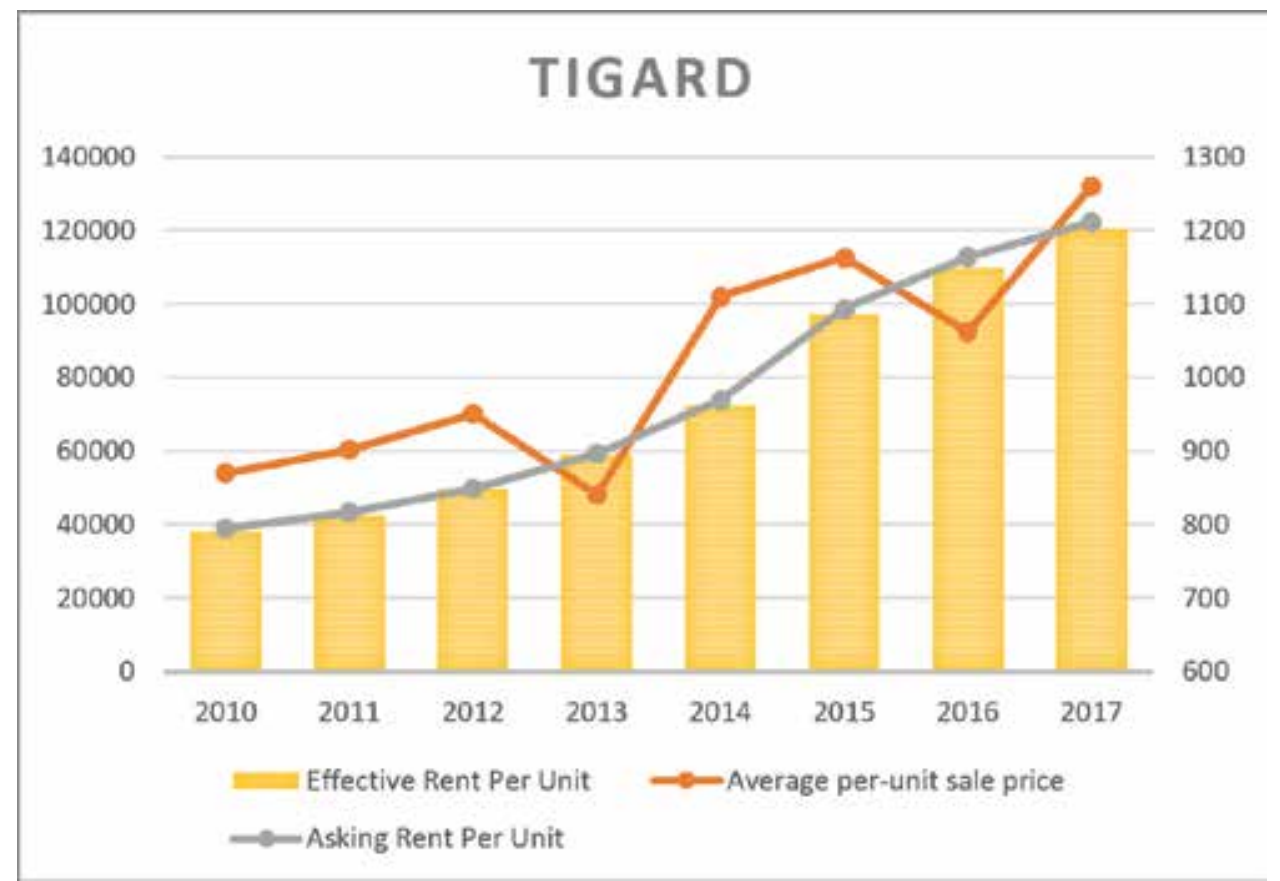

Source: CoStar Sales COMPS database 
Fig. 24 - Change in rent and per-unit sale price in SW Corridor, 2010-17, as of 8/10/17

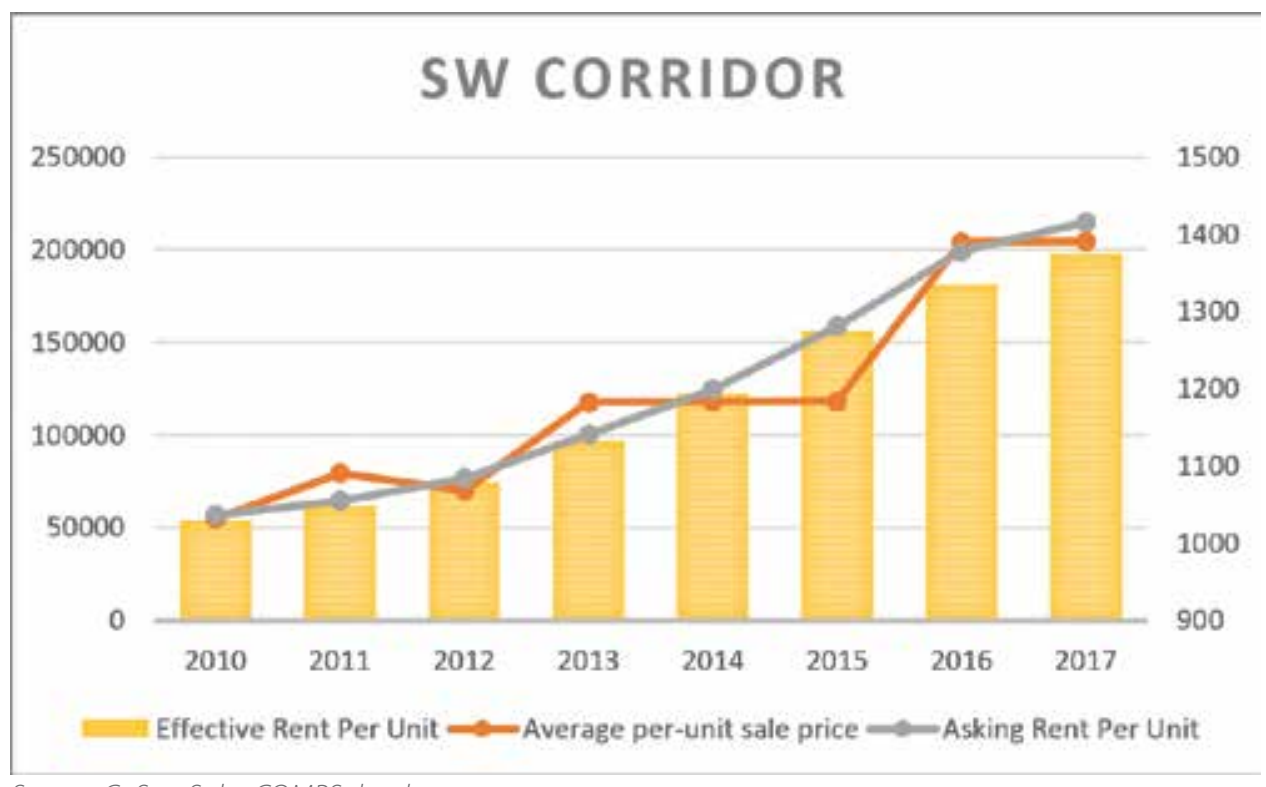

Source: CoStar Sales COMPS database

The average price per unit increases as star rating goes up. Portland has the highest price per unit for 2 star and 3 star rental properties, while Tigard marks the lowest price per unit for all star rating properties for the last decade. Southwest corridor sales prices are more than the average in the cities; it has the highest price per unit for 4 and 5 star apartments.

Fig. 25 - Average sale price per unit by star rating between 2006 and 2017, as of 8/10/17

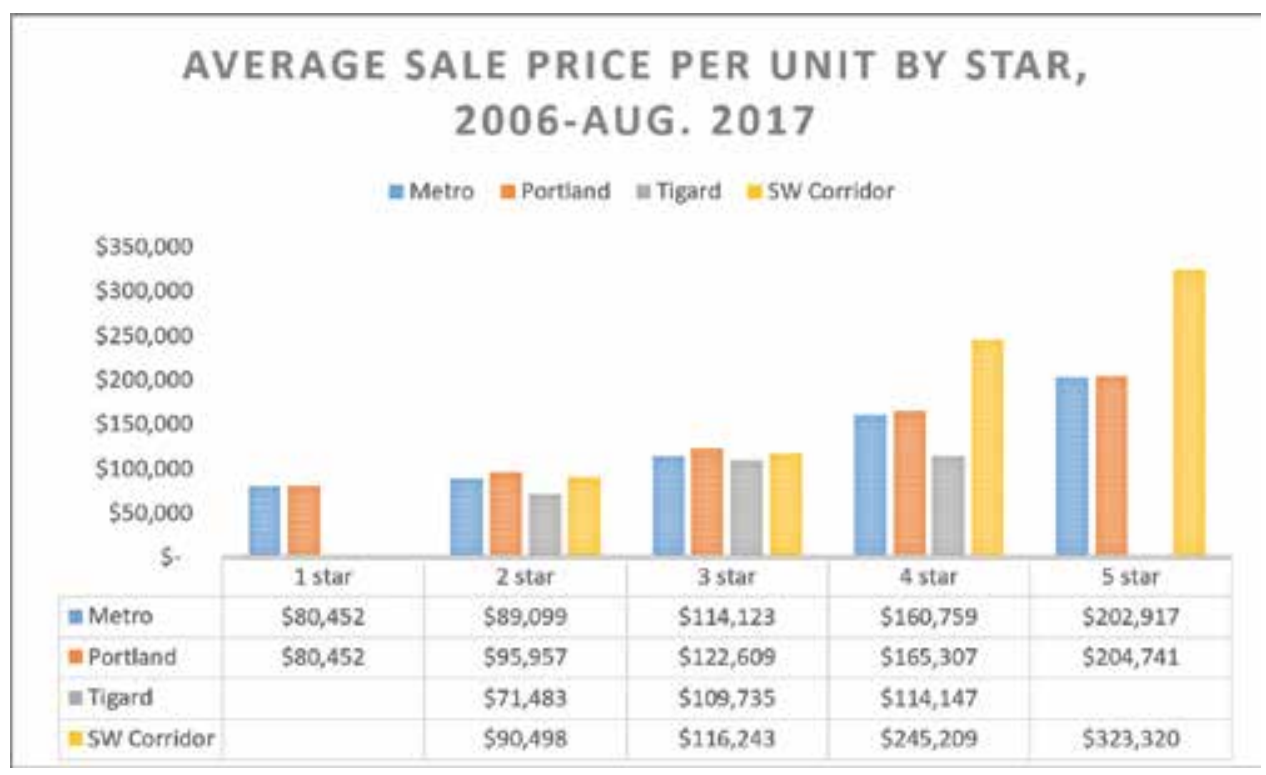

Source: CoStar Multi-Family Property database 


\section{Very recent market acceleration}

The multifamily market has been accelerating since the recession, and particularly the NOAH market has been very brisk. Regionally, 21 percent of the units sold between 2006 and 2017 occurred just in this last year. In particular, 90 percent of total apartment building sales and 72 percent of the units sold in the metro in 2016 and 2017 were NOAH properties.

The vast majority of multifamily property sales in Portland, Tigard, and along the Southwest corridor have occurred in the post-recession period; with greater shares during just the last year and a half (2016 through August 2017). Overall, for 3 star properties, two-thirds of sales have occurred in this very recent period; for 2 star properties, one third of the decade's sales have been in the past year and a half. NOAH accounts for 60 percent of units sold last year along the Southwest corridor.

Table 7 - Number of units and properties sold between 2016 and 2017, as of 8/10/17

\begin{tabular}{|c|c|c|c|c|}
\hline Star & Metro & Portland & Tigard & SW Corridor \\
\hline & $7(1)$ & $7(1)$ & 0 & 0 \\
\hline & 4,874 (328) & 2,499 (203) & $78(6)$ & $394(26)$ \\
\hline & 9,093 (118) & $5,631(79)$ & $190(2)$ & $441(8)$ \\
\hline & $4,984(44)$ & $1,686(31)$ & 0 & $559(4)$ \\
\hline & $461(4)$ & $94(2)$ & 0 & 0 \\
\hline Total & $\begin{array}{c}19,438 \text { units } \\
\text { (495 properties) }\end{array}$ & $\begin{array}{c}\text { 9,916 units } \\
\text { (315 properties) }\end{array}$ & $\begin{array}{c}268 \text { units } \\
\text { (8 properties) }\end{array}$ & $\begin{array}{c}\text { 1,394 units } \\
\text { (38 properties) }\end{array}$ \\
\hline
\end{tabular}

Source: CoStar Multi-Family Property database

Fig. 26 - Average price per unit of NOAH vs 4 and 5 star properties, 2016-17, as of 8/10/17

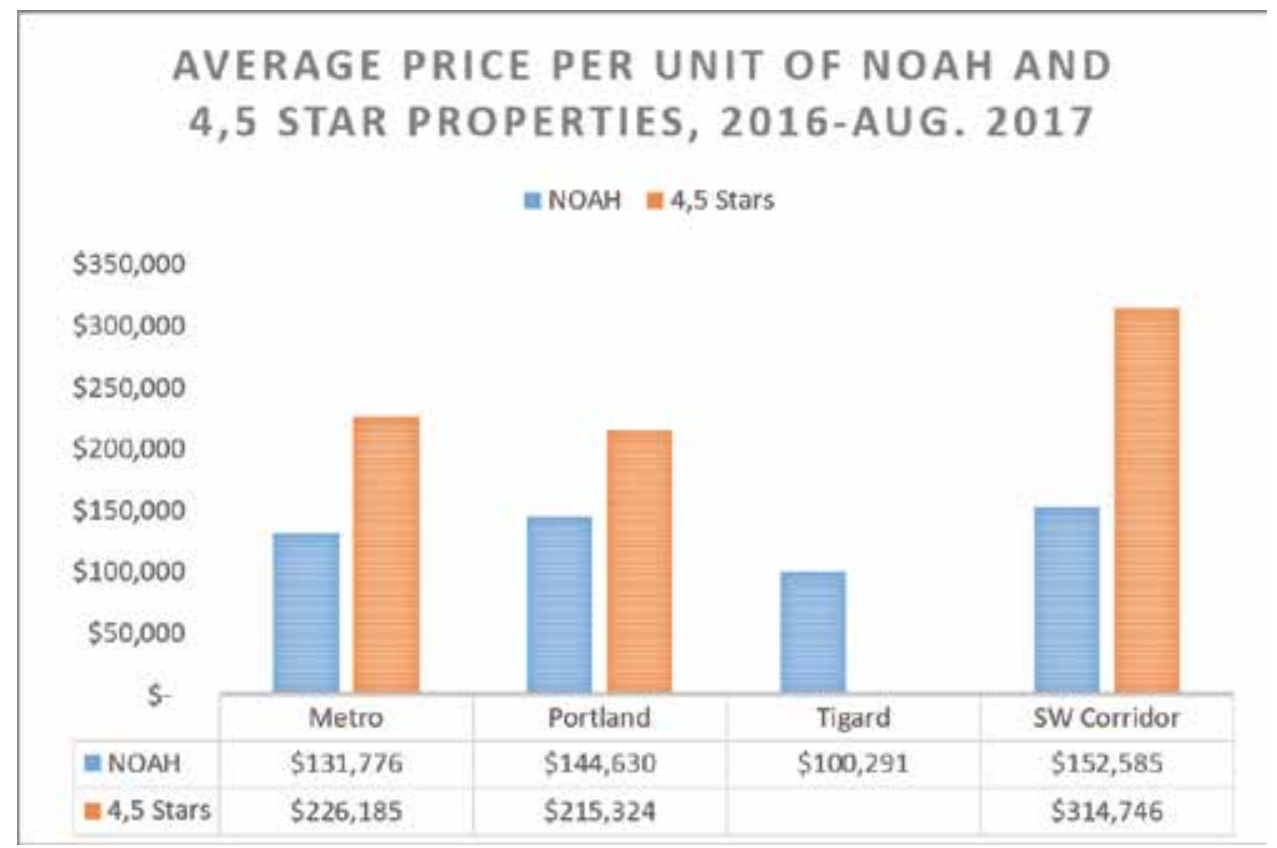

Source: CoStar Multi-Family Property database 
The very current look at average price per unit by quality of rental housing shows the great difference between $\mathrm{NOAH}$ and high quality rental properties. Regionally, the price per unit of 4 and 5 star apartments is 172 percent of that of NOAH. However, the increase in price per unit for two and three star properties suggests that these will be lost to the affordable stock.

\section{Geography of sales}

From 2010 to 2017, a total 65,263 units were sold in 1,643 transactions of apartment buildings in the metro area. The city of Portland accounts for 42 percent of these units sold, while 3 percent of units sold were located in Tigard. Regionally, great increases in sales occurred in the time period between 2010 and 2011, and between 2014 and 2015.

When mapped, the Portland sales show a large clustering in Northwest Portland and upper Southeast Portland neighborhoods..

Approximately 37 percent of units sold in two star apartments along SW corridor happened in Tigard, 40 percent of units sold in three star apartments were located in Portland. 70 percent of units sold in four and five star apartments along SW corridor occurred in the Southwest waterfront in Portland.

Fig. 27 - Map of rental housing property sales in Metro, 2010-17, as of 8/10/17

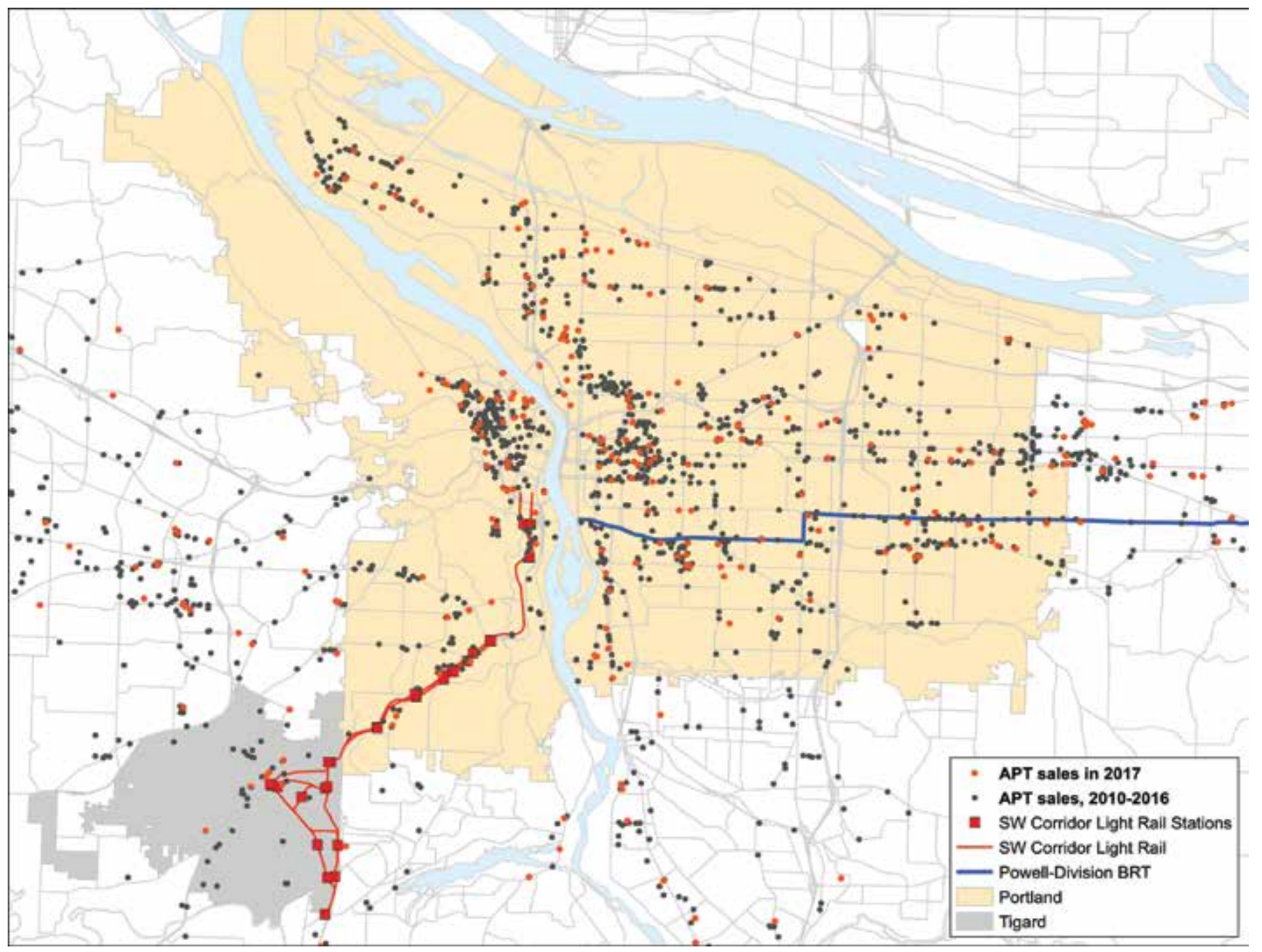

Source: CoStar Sales COMPS database 


\section{Apartment property sales in Portland, 2010-17}

Between 2010 and 2017, 1,054 apartment properties were sold in the city of Portland.

Approximately, 23 percent of total units in the city were sold, 21,942 units sold. 68 percent of sales were 1 and 2 star apartments, which accounted for 40 percent of units sold during the time period. Sales for 4 and 5 star apartment buildings were relatively less than the lower quality apartment buildings, however, units sold in high quality apartments were 28 percent of total units sold during the last six years.

Table 8 - Sales of rental housing properties and units in Portland by neighborhood, 2010-17, as of $8 / 10 / 17$

\begin{tabular}{r|r|r|r|r} 
Neighborhood (Neighborhood coalition) & Sales & $\begin{array}{c}\text { Units } \\
\text { sold }\end{array}$ & $\begin{array}{c}\text { Units } \\
\text { overall }\end{array}$ & $\begin{array}{c}\text { Percent of all } \\
\text { rental units }\end{array}$ \\
Central Northeast Portland (CNN) & 44 & 734 & 3,863 & $19.0 \%$ \\
\hline East Portland (EPNO) & 203 & 4,845 & 13,072 & $37.1 \%$ \\
\hline Northeast Portland (NECN) & 90 & 1,294 & 7,604 & $17.0 \%$ \\
\hline North Portland (NPNS) & 109 & 1,924 & 5,202 & $37.0 \%$ \\
\hline Northwest Portland (NWNW) & 158 & 8,791 & 22,770 & $38.6 \%$ \\
\hline Southeast Portland (SEUL) & 313 & 4,106 & 16,615 & $24.7 \%$ \\
\hline Southwest Portland (SWNI) & 79 & 1,408 & 7,287 & $19.3 \%$ \\
\hline
\end{tabular}

Source: CoStar Sales COMPS database

Southeast Portland was the top neighborhood as it accounted for 30 percent of all apartment property sales in the city. The units sold in Southeast Portland accounted for 20 percent of all rental units in the neighborhood. East Portland and Northwest Portland have significant shares (37 percent altogether) of apartment sales during the period. In particular, 34 percent of all rental units in East Portland were sold during the last six years. Units sold in North Portland neighborhood accounted for 34 percent of all rental units in the neighborhood.

A half of 2 star apartment units sold occurred in East Portland and Southeast Portland, while most luxury apartment units sold were disproportionately located in Northwest Portland. 
Fig. 28 - Map of rental housing property sales in Portland, 2010-17

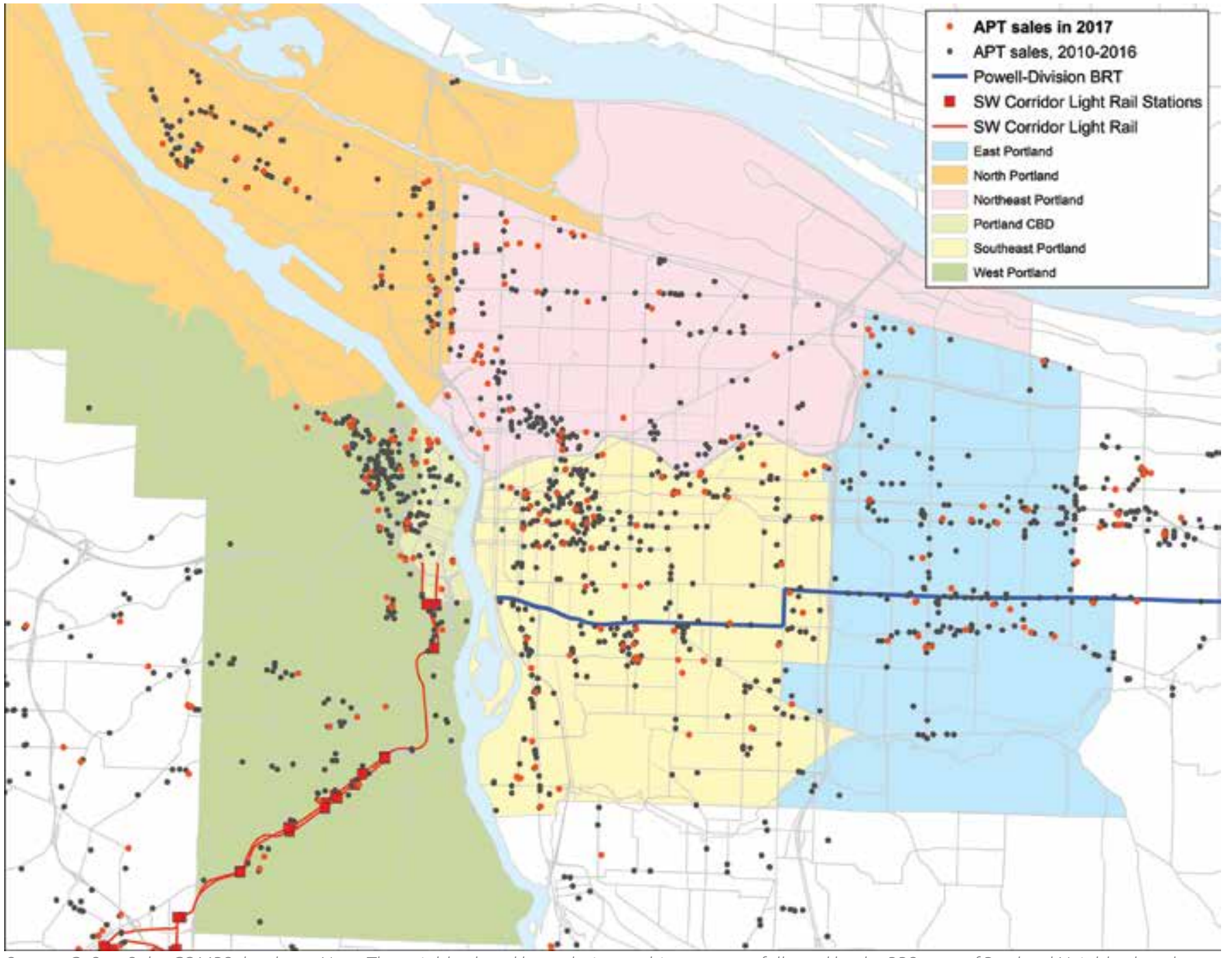

Source: CoStar Sales COMPS database. Note: The neighborhood boundaries on this map were followed by the BPS map of Portland Neighborhood Associations (2017). 


\section{Apartment property sales in Tigard, 2010-17}

A total of 30 transactions occurred between 2010 and 2016. All apartment buildings sold were 2 star buildings (23) and 3 star buildings (7). Although most transactions were 2 star apartment properties, the share of units sold were almost even between 2 star building sales and 3 star building sales.

As the data includes repeated sales, the results showed that 2 rental properties have been sold repeatedly during the time period. Although one is a senior housing property, the other is 2 star apartment having 7 units. This property was sold in 2012 and 2016.

Most properties sold in Tigard are disproportionately located in downtown Tigard, along highway 99W after the intersection between highway 217 and 99W. In particular, a significant number of properties sold were near SW Greenburg Rd and SW Hall Blvd.

Fig. 29 - Map of rental housing property sales in Tigard, 2010-17

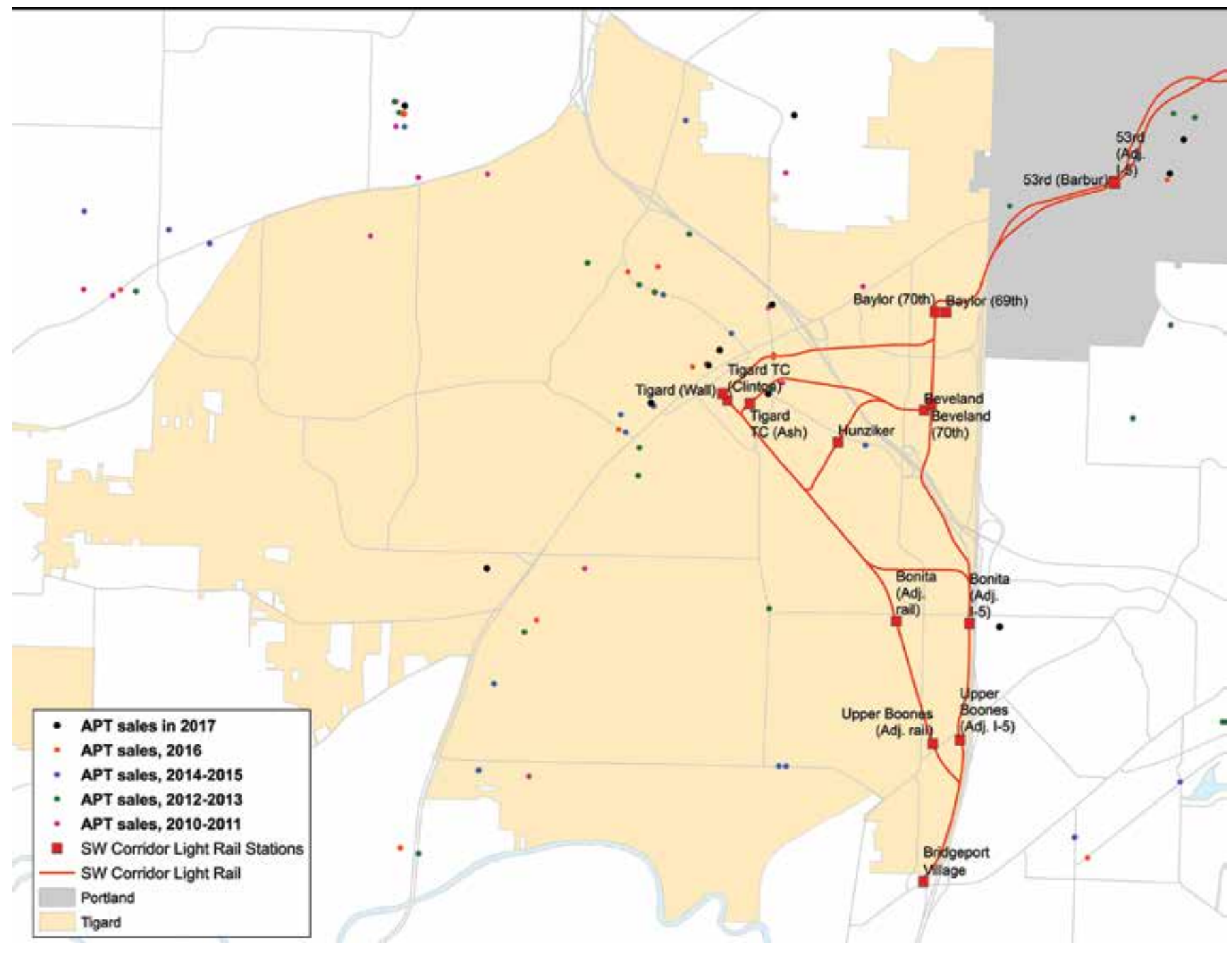

Source: CoStar Sales COMPS database 


\section{Demographics of apartment property sales}

Apartment sales are most prevalent in low income tracts and racially diverse tracts. While the demographics of individual buildings are not available, it is likely that the sales of market affordable housing are destabilizing these vulnerable households and up-scaling is constraining the housing choices of low income renters, especially in communities of color, given these patterns.

\section{Income}

At all geographies, low-income tracts (incomes between $\$ 40,000$ and $\$ 59,000$ ) have the highest share of units sold. Nearly half of the multi-family units sold in the metro region were located in these low-income tracts. In Portland, a similar proportion, about half the units, were sold in low-income tracts. However, in Tigard, threequarters of the units sold were in these low-income tracts.

Focusing on the Southwest corridor, very low-income tracts ( $\$ 20,000$ to 39,000 income) have the highest proportion of apartment units sold during the past decade, at 41 percent. The low-income tracts accounted for another 35 percent of units sold. Metro-wide, very low-income tracts in the metro area accounted for 20 percent of total units sold, so the Southwest corridor sales have a disproportionate impact in very low-income areas.

Fig. 30 - Units sold by census tract median income in Metro, 2010-17, as of 8/10/17

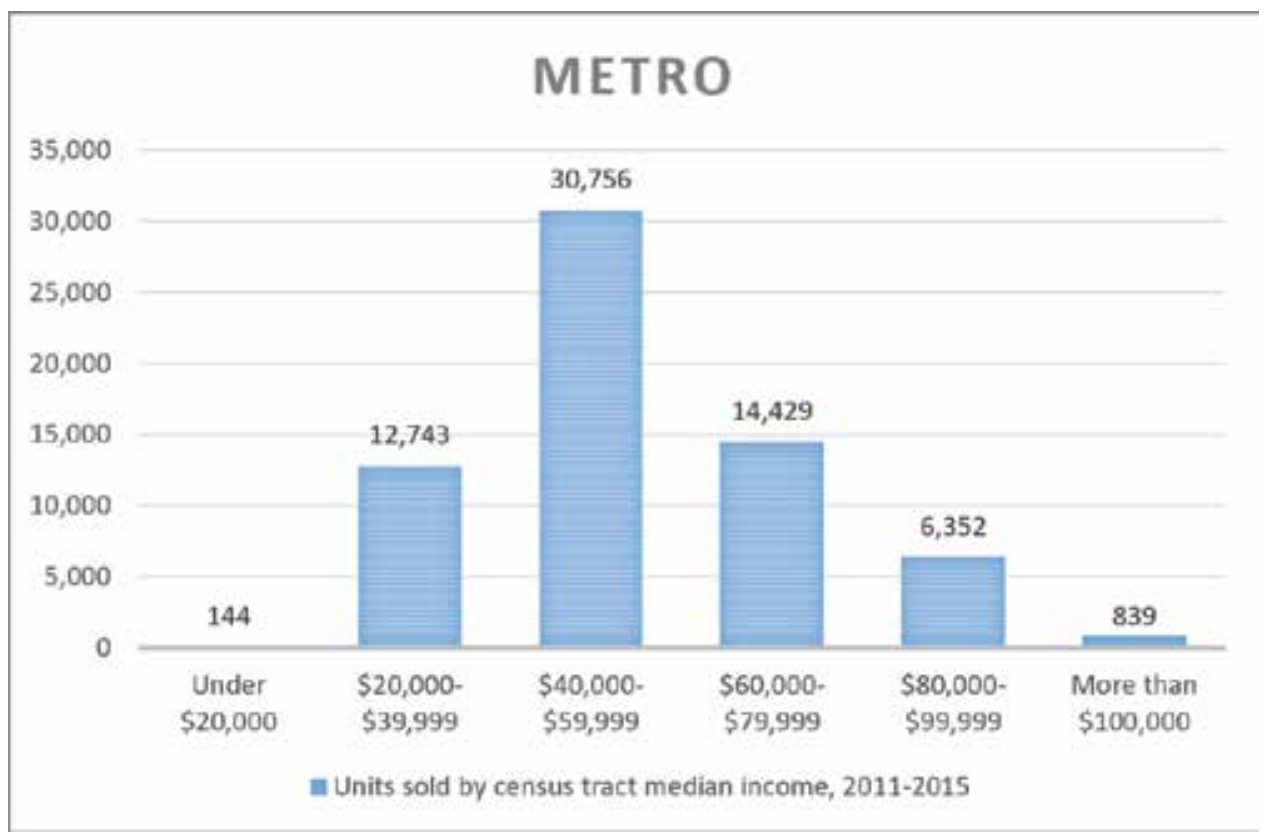

Sources: CoStar Sales COMPS database, 2011-15 ACS 
Fig. 31 - Units sold by census tract median income in Portland, 2010-17, as of 8/10/17

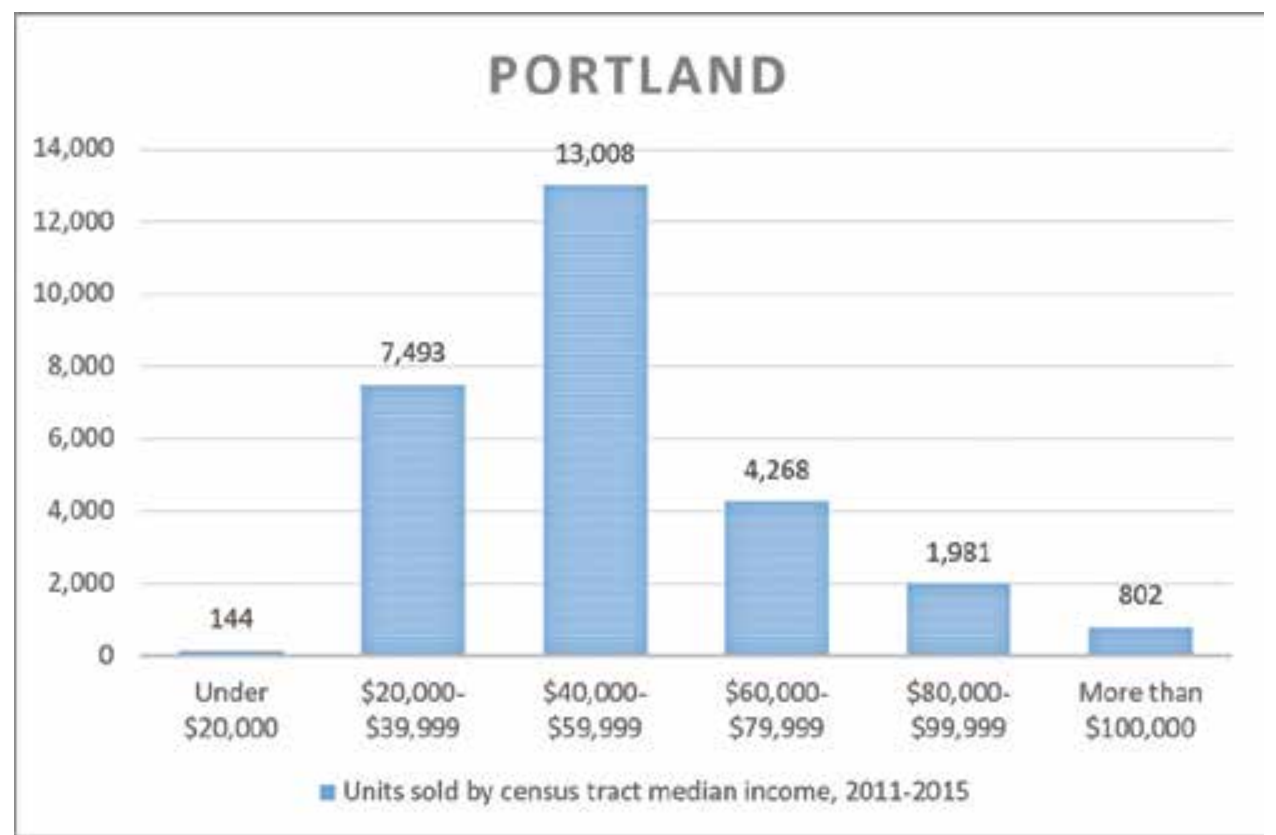

Sources: CoStar Sales COMPS database, 2011-15 ACS

Fig. 32 - Units sold by census tract median income in Tigard, 2010-17, as of 8/1017

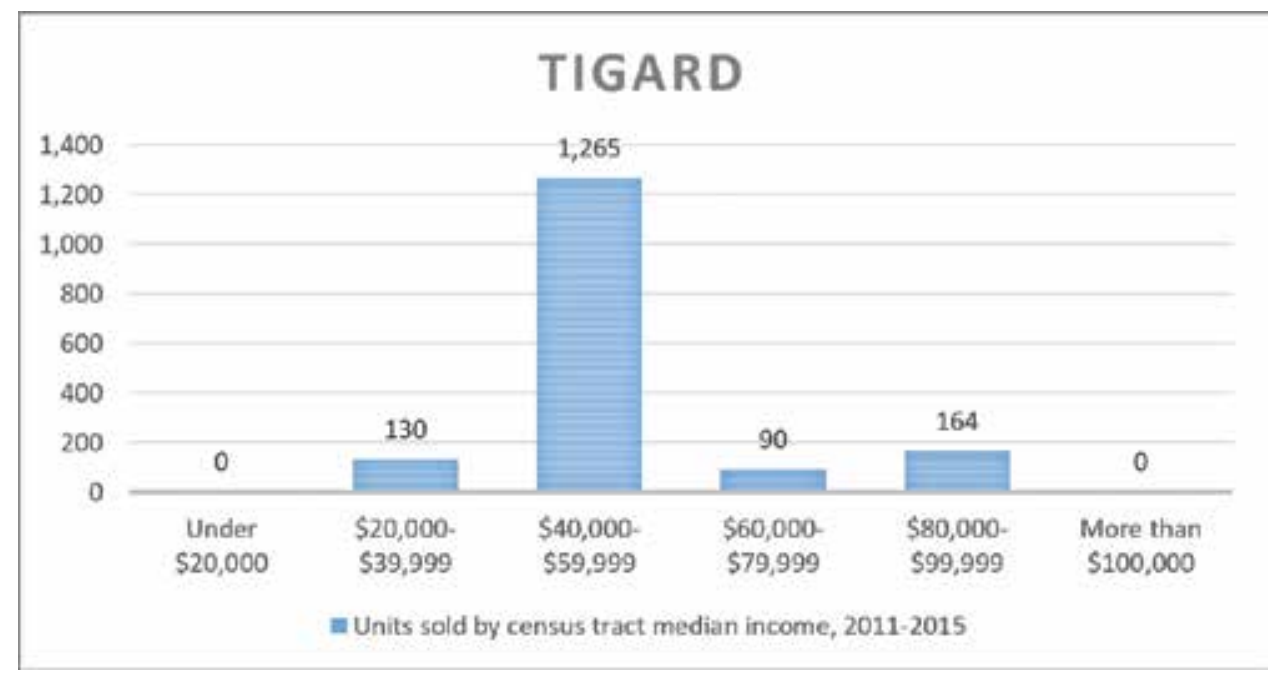

Sources: CoStar Sales COMPS database, 2011-15 ACS 
Fig. 33 - Units sold by census tract median income in SW Corridor, 2010-17, as of 8/10/17

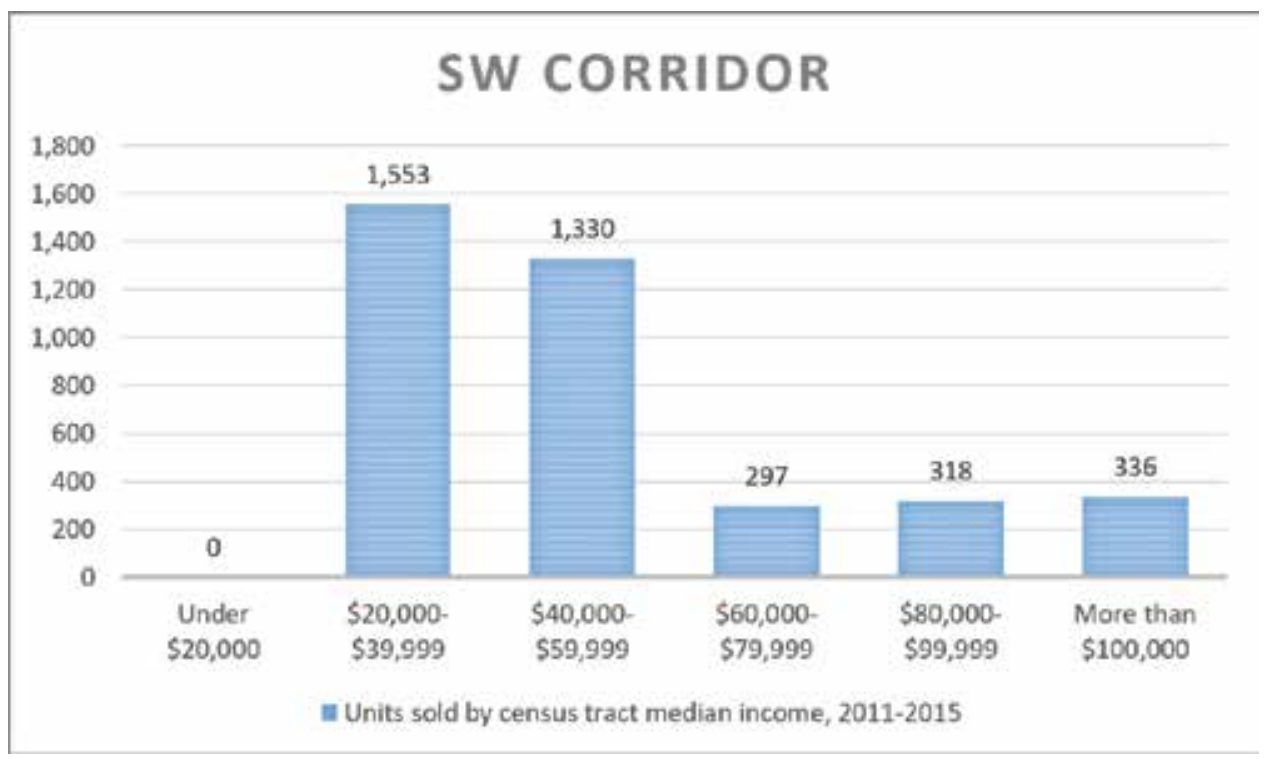

Sources: CoStar Sales COMPS database, 2011-15 ACS 


\section{Apartment property sales and race, 2010-2017}

Between 2010 and 2017, over half of all units sold were located in racially diverse tracts, with 89 percent of those sales in the two-three star NOAH category. These transactions in racially diverse tracts total 26,222 units of $\mathrm{NOAH}$ sold in the region.

Fig. 34 - Metro: Map of rental housing property sales (2010-17) and percentage of people of color by census tract in 2015

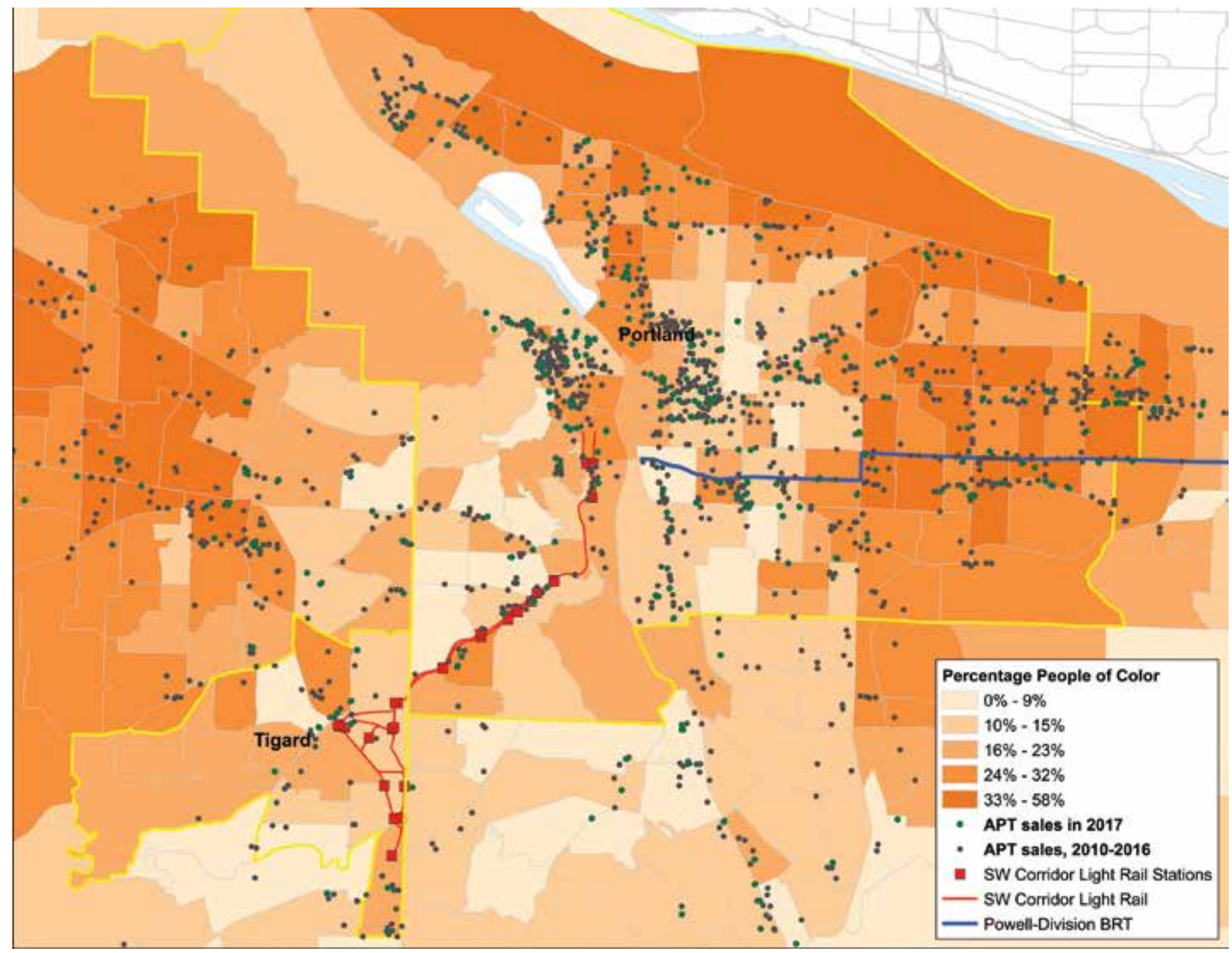

Sources: CoStar Sales COMPS database, 2011-2015 ACS 
Fig. 35 - Portland: Map of rental housing property sales (2010-17) and percentage of people of color by census tract in 2015

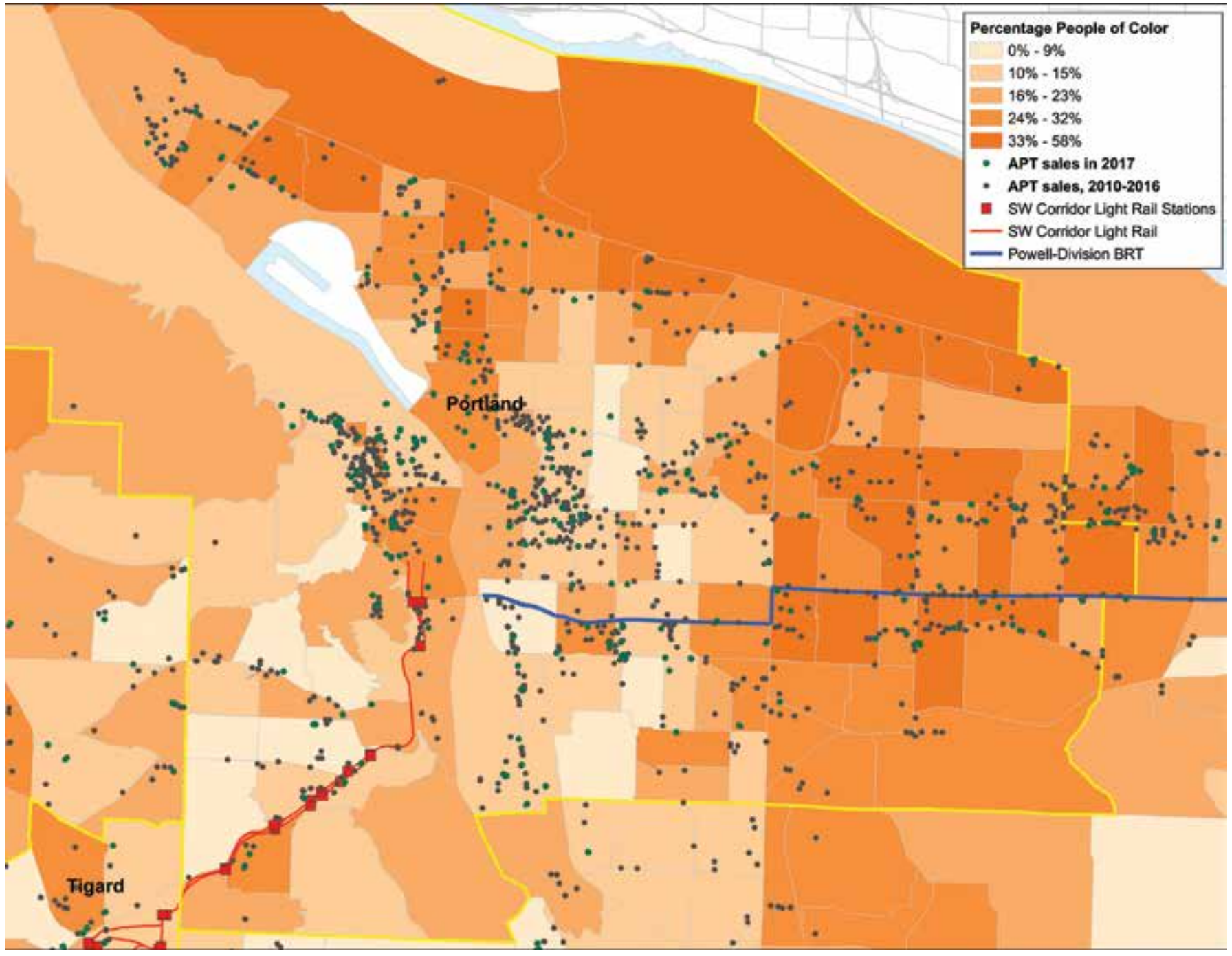

Sources: CoStar Sales COMPS database, 2011-15 ACS

From 2010 to 2017, 54 percent of total units sold in Portland were made in racially diverse tracts. Of these, over three-quarters (11,378 units in 479 properties) were $\mathrm{NOAH}$. In fact, of sales in racially diverse tracts, nearly all were $\mathrm{NOAH}$ type housing.

About a third of the units sold in Tigard were located in racially diverse tracts. All transactions (13 properties) in racially diverse tracts were NOAH properties - about evenly split between two and three star apartments. The most recent apartment sales in racially diverse tracts in Tigard occurred in 2016. One 3 star property having 156 units was sold, while sales of two 2 star apartments resulted in 44 units being sold. Those apartments sold in 2016 were located close to downtown Tigard in tracts that are both racially diverse and low income.

Along the Southwest corridor, 38 percent of all units sold were in racially diverse census tracts, with about half (738 units) of those units being NOAH types. 
Fig. 36 - Tigard: Map of rental housing property sales (2010-17) and percentage of people of color by census tract in 2015

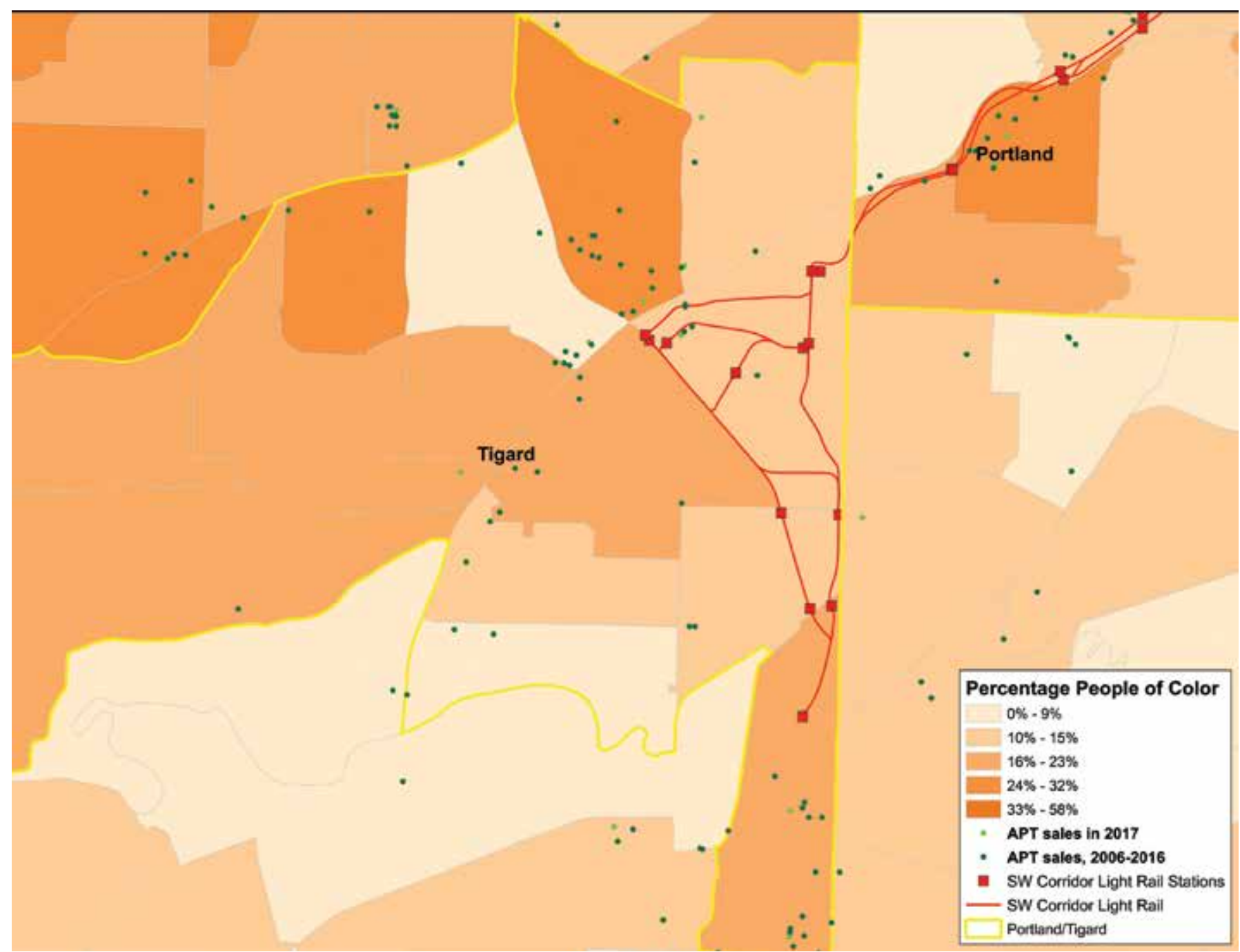

Sources: CoStar Sales COMPS database, 2011-15 ACS 
Fig. 37 - SW Corridor: Map of rental housing property sales (2010-17) and percentage of people of color by census tract in 2015

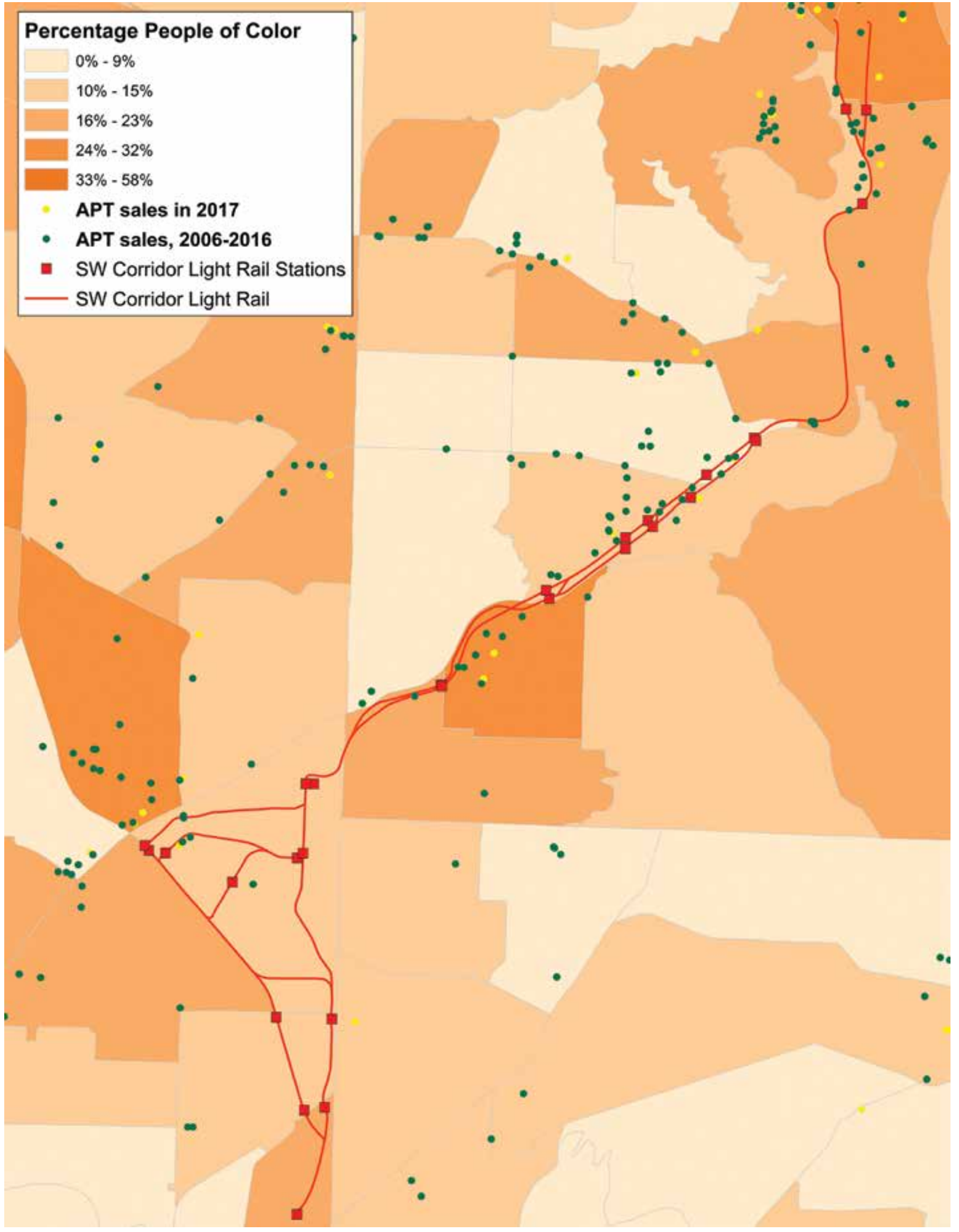




\section{High Volume Tracts are areas of concentrated sales}

In order to analyze the areas of concentrated multifamily sales, we look at High Volume Tracts (HVTs). The HVT is a tract where the number of units sold in the tract is at or above the 80th percentile of sales per tract for the area. The regional HVT threshold is just under 350 units sold in a tract; there are 53 tracts that are HVTs in the metro area. Overall, 65 percent of units sold were located in HVTs.

Since 2010, 56 percent of NOAH units sold (over 26,000 units) in the Portland region were in these concentrated sales areas. These areas also have substantial numbers of sales to high-quality apartments - 85 percent of $4-5$ star sales are in HVTs. The HVTs are hot market areas.

Among the regional HVTs, 33 tracts were also identified as racially diverse; and 40 percent of all units sold were located in racially diverse, high volume census tracts. In Portland, almost 60 percent of transacting units were in racially diverse HVTs, with the majority of those in the NOAH categories. In the very recent sales recorded along the Southwest corridor, over a quarter of units sold were in racially diverse HVTs.

Low income tracts are 36 of the HVTs, and more than a third of the multifamily units sold in the region were in these low income HVTs.

Nearly twenty thousand NOAH units were sold in low-income, racially diverse high volume tracts in the past decade -42 percent of the $\mathrm{NOAH}$ units transacted during this time. 


\section{Local Policy Responses to NOAH Preservation Opportunities}

In the past several years, preserving affordable rental housing - both NOAH type units and expiring subsidy units - has received new attention in the policy and finance world. For high cost cities in particular, preservation is the new construction. Programs to preserve low-cost rental housing vary depending on the targets (market or subsidized housing), the developer/owners (non-or for-profit), and the goals with respect to tenant income and neighborhood focus. The following provides baseline information about preservation programs that are relevant for the region's discussion in the Southwest Corridor and elsewhere, as the market for NOAH multifamily housing threatens housing affordability for thousands of tenants.

\section{Considerations in evaluating policy practices:}

- All of these programs begin with the buy-in and substantial financial contributions across the public, philanthropic, and private sector. Processes to set up collaboration, the approach, and to determine the structure of programs can take time and resources to develop and finalize.

- Despite this time to program launch, once created, funds have goals of 'quick strike' and moving as fast as the market. The capacity of developer/managers' Identifying properties and assembling the funds to acquire them must be strong to be able to act quickly.

- Financing structures that support multifamily housing to continue to operate without subsidy have household income levels around 60-80 percent AMI (of course, the buildings tend to be currently housing tenants in/near this income range, rather than those with extremely low incomes).

- Many programs work with mostly private/for profit buyer/managers and therefore have terms of affordability that are substantially shorter than the Portland norm (similar to the LIHTC program, buildings can be sold or refinanced at market rates after the term). The Denver program, managed by a Community Land Trust, is a notable exception. In the REIT model (as in HPET), the investment fund maintains ownership of the properties with income from the stream of rents and the affordability can be long term.

\section{Network for Oregon Affordable Housing's Oregon Housing Acquisition Fund}

Impetus and goals. NOAH is a Community Development Financial Institution, established by Oregon banks to increase affordable housing; and the organization has new goals to increase lending through 2020. Its fund for acquisition and preservation provides financing for market affordable multifamily and for rental housing with expiring federal subsidies, using a mix of philanthropic, public, and traditional bank capital sources.

- Program targets. The Oregon Housing Acquisition Fund (OHAF) Market Rate Conversion Loans are used to transition market housing to affordable housing, rented with 51 percent of the units below 80 percent AMI rents or 40 percent of units must be affordable at 60 percent AMI or 20 percent of units affordable at 50 percent AMI. Long-term affordability terms are required.

Nonprofit and for profit entities are eligible borrowers, as are public corporations. Loans have primarily been made to nonprofit developers. NOAH works statewide.

- Financing Structure. OHAF is a short-term financing pool that has a maximum loan of $\$ 5$ million for a term of 3 years with a 12-month extension. The average repayment is under 3 years. Interest rate is 2 to 5 percent depending on product. Payments are interest only. Its funds are a mix of philanthropic, public and bank capital.

- Challenges. With the exit of MacArthur Foundation from housing programs, NOAH is in need of additional low cost funds to provide the foundation of their capital stack. ( ${ }^{*}$ this is likely a challenge for several of the reviewed funds given MacArthur's withdrawal)

- More information: https://noah-housing.org/financing/acquisition-and-preservation/ 


\section{Greater Minnesota Housing Fund's NOAH Impact Fund}

Impetus and goals. Minnesota Housing Partnerships'studies of NOAH housing in the Minneapolis-St. Paul 7 county region showed substantial losses of affordable housing to sales and upgrading. After studying market segments, MHP focused on larger multifamily apartments that are on the market for sale.

The NOAH Impact Fund has a goal of capturing 10 percent of the annual sales of units of moderate-lower quality apartment buildings - preventing 2-3,000 households from being displaced.

- Program targets. The NOAH Impact fund targets Class B and C rental buildings with more than 50 units that are not subsidized. According to fund manager Rachel Robinson, at the 50-100 unit size, economies of scale reduce transactions costs, providing a bang for the buck, and allow for a more market-like financing structure. The ideal building size, however, is more than 100 units.

The buildings targeted by the NOAH Impact fund have rents affordable in the 60-80 percent AMI range; the program does fund mixed-income buildings, but three-quarters of tenants must be below 80 percent AMI. Tenants must qualify by income, but managers are not required to create extensive compliance procedures beyond income.

Most of the buildings financed by the fund have been in 'opportunity areas' that are changing, with new and replacement housing that is more upscale. In these areas, buildings often sell without being listed, and private market actors with access to information about sales are able to act quickly to purchase and evict tenants.

- Financing structure. Given the market conditions and lack of tenant protections, the fund seeks to be "nimble" and serve as a "quick strike" against housing loss. Property transactions can be approved in a few days, with closing in 90 days, comparable to a routine transaction.

The fund was capitalized with $\$ 25$ million dollars; The fund acts as the equity partner for developer-managers proposing property acquisition. Buildings will remain affordable for 15 years, with the Fund exiting the deal after 10 years.

The rotating fund has a capital stack that includes public sector, philanthropic, and banks. Philanthropic foundations (GMHF, McKnight) provided funds $(\$ 6 \mathrm{~m})$ for credit enhancement. The Hennepin County government provided $\$ 3 \mathrm{~m}$ in capital that may not be paid back. The Minnesota Housing Finance Agency is a patient capital investor, with a low interest loan to the fund; and finally three local banks provided the senior loan capital. Investors see predictable returns and the fund is repaid when owners refinance or sell after 10 years.

- Challenges. As the fund has been operating, the costs per unit for purchase have increased quite a bit, from $\$ 60-90,000$ per unit up to 1.5 times that amount, with additional costs for renovating to a habitable standard. However, high median incomes in the area mean that rents are sufficient at this time.

- More information: http://gmhf.com/finance/noah-impact-fund/

\section{Sources:}

- Rachel Robinson, personal interview. 8-16-16

- NOAH Impact Fund investment term sheet. 6-1-2017. Provided by R. Robinson.

- "Sold Out" report, Minneapolis Housing partnership report. 


\section{Denver TOD Fund}

Impetus and goals. With a major public transit expansion, including light rail, commuter rail, and bus rapid transit, Denver was poised to address its extremely high housing + transportation cost index. In 2010, Enterprise Community Partners and Denver-area partners launched a first-of-its-kind fund to create and preserve affordable housing along current and future transit corridors in the City of Denver.

- Program targets. The TOD fund started as a program with the Urban Land Conservancy, Denver's Community Land Trust that holds multifamily properties, community facilities, and commercial spaces. ULC acquires and holds sites and describes its model as "in-placement" for residents, rather than anti-displacement (per ULC VP Tony Pickett). The goal was to preserve 1000 units of housing near new and future transit stations, and to include commercial space as part of a larger economic development strategy.

The fund has now expanded regionally and with additional borrowers working to preserve NOAH housing outside the city of Denver.

Multifamily housing can be rental or owner-occupied. Rental housing incomes are 60 percent AMI and below; while for-sale unit incomes can be up to 95 percent of AMI. Projects to date have included supportive housing, workforce housing, and senior housing. Some projects are new construction, while others have been for preservation.

The fund targets across several neighborhood types, and its investments are balanced among preservation in transitioning (gentrifying) areas, stabilization in distressed communities, and inserting affordability into desirable, amenity rich areas. The sites are near to current and planned rail or high frequency bus stations.

- Financing Structure. The TOD fund was capitalized with \$15 million from Enterprise, the City, and ULC, and has grown to $\$ 24$ million. ULC continues to lead the real estate acquisition strategy and works with other developers.

Acting quickly to underwrite and close loans is an important factor for the TOD fund. Loans can be up to $\$ 5$ million.

The TOD fund capital stack includes public and philanthropic sector as well as traditional loan capital. Borrowers provide 10 percent cash equity for purchases; public dollars provide credit enhancement. The philanthropic grant and program-related investment capital receives a modest financial return. Banks and CDFIs participate as CRA-eligible lending; and Enterprise Community loan fund acts as the fund manager and senior lender. Many projects include LIHTC from the Colorado Housing and Finance Agency.

- Challenges. With limited LIHTC availability and other resource constraints, ULC has to hold land awaiting developers' assembly of financing beyond the fund. The expansion of the TOD fund outside of the City of Denver is an important goal, given the regional expansion of light rail and increasing costs and suburbanization of poverty; however, it has been difficult due to smaller municipal budgets and less buy-in to the concept of affordable housing near transit.

- More information: https://www.urbanlandc.org/denver-transit-oriented-development-fund/

\section{Sources:}

- Urban Land Conservancy TOD Fund

- Denver TOD Fund: A strategic funding tool to preserve and create affordable housing near transit.

- Confronting Suburban Poverty in America report. Brookings Institute. 2014.

- Enterprise Community Partners TOD fund term sheet.

- Interview, Tony Pickett, ULC. Shelterforce. 7-18-2014. 


\section{Bay Area Transit Oriented Affordable Housing Fund}

Impetus and goals. The Bay Area is facing extraordinarily high housing costs, with households moving to distant suburbs to save on housing and then experiencing high transportation costs. Transit use can help households to save money, if there is sufficient housing near transit. As the region conducted planning for more compact land use and connecting transportation and housing with land use and climate change/GHG reduction, local organizations created a workgroup on housing. Urban Land Institute, SPUR, and the Great Communities Collaborative (community and national foundations) created a workgroup to assess the potential for a fund.

- Program targets. The TOAH fund works across the nine county Bay Area. It funds housing, mixed use development, and community facilities for low income people' use. There is equal priority in the fund given to preservation and new construction.

The fund has an overall affordability target of 75 percent of units affordable at 80 percent $\mathrm{AMI}$ across all its investments. For multifamily rental housing, the project by project target is 20 percent of units affordable at 50 percent AMI or 40 percent of units at 60 percent AMI. According to the Great Communities' background report, there was extensive debate over income targets and the feasibility of financing only affordable housing during the four year start up period.

The Association of Bay Area Governments (ABAG) with MTC designates Priority Development Areas that are sites with opportunities for infill development or preservation that are pedestrian friendly and within a half mile of quality transit service.

- Financing Structure. The TOAH fund was capitalized with $\$ 50 \mathrm{~m}$, including $\$ 10 \mathrm{~m}$ from the regional transit agency, MTC. Like the other funds, it includes a capital stack with philanthropic and public funds; banks, and CDFIs. The combination of sources of funds stretches what would be possible with CDFI capital alone-longer terms, higher LTVs, and higher loan sizes with lower interest rates.

The Low Income Investment Fund (LIIF) is the fund manager and originating lender, with 5 CDFIs (including Enterprise and LISC); Citi Capital and Morgan Stanley; and initial investments from Ford Foundation and the San Francisco Foundation.

The TOAH fund has 5 loan products, with up to 7 year lending terms. It can fund acquisition, but also construction, predevelopment, and bridge funding. Applicants must show that the fund is needed for project feasibility.

- Challenges. As of late September 2017, the TOAH fund is on hiatus "as we work to retool the program to respond to the current and future needs of the Bay Area." Great Communities.

- More Information: www.bayareatod.com

\section{Sources:}

- Bay Area TOAH: Assessment and Lessons Learned. May 2013, prepared by Seifel Consulting and ICF international. 


\section{Regional Equitable Development Initiative Fund-Puget Sound}

Impetus and goals. Puget Sound Regional Council led the Growing Transit Communities Partnership along with Vision 2040 plan to develop programs for "thriving and equitable transit communities." During this three year process, the work of fund establishment was started with Enterprise Community Partners and Impact capital CDFI.

A key challenged noted was that existing CDFIs were limited in their effectiveness in NOAH preservation by lower LTVs and higher interest rates than borrowers could afford. Other funds for affordable housing required deep and long term affordability targeting, or were geographically limited, or were only available for nonprofits. The REDI sought to address other market actors and make it possible to work in concert with transit planning to assemble sites and land use approvals over a longer period of time.

- Program targets. The REDI is expected to add/preserve 500-700 affordable housing units during its first round of lending. It can be used to purchase buildings with existing market affordability (NOAH) or with expiring subsidies that could be renewed. REDI can also be used to fund community facilities and nonprofit space.

REDI funds mixed income housing development. The preservation projects' housing is targeted to 80 percent AMI households. There must be 10 percent of units affordable at 80 percent AMI (or with rents at 20 percent below market rate). However, the fund seeks to maximize affordability on site and the overall fund affordability must reach 25 percent of units affordable to 50 percent AMI households. There is also a goal of having 15 units available for below 30 percent AMI tenants.

Sites are in transit oriented areas near to rail or frequent service bus or streetcar.

- Financing Structure. The REDI includes public investments, philanthropic funds and program-related investments, and senior capital from the two main CDFls involved in its origination. The fund has started with \$21 m available.

The REDI is a revolving loan structure, which is expected to be recirculated in 3-5 years as borrowers secure permanent takeout financing.

The fund is more flexible than public dollars in that there are no minority/women owned business requirements on contracting.

- Challenges. This fund is market-oriented and is working on incorporating public sector values and thinking. Abello reports that the fund is structured to include two seats for public sector representatives on the five seat lending committee. These public sector representatives may rotate with project location. He quotes: "It will be a little bit of a learning curve," says Devin Culbertson, Enterprise senior program director. "Things we think about in approving loans are different, public versus private sector, but that's part of the challenge and the risk."

\section{Sources:}

- Central Puget Sound Regional Equitable Development Initiative Fund. Business Plan Framework, 2014.

- Enterprise Community Partners, REDI fund information sheet.

- Abello, OP. "Seattle starts \$21m loan fund to promote affordable housing near transit." Next City, 12-14-2016.

- Capps, K. "Battling inequality, Seattle bets on transit-oriented housing." Citylab. 12-14-2016. 


\section{Housing Partnership Equity Trust (HPET)}

Impetus and goals. The HPET was launched in 2013 as a social purpose REIT—Real Estate Investment Trustworking with 14 nonprofit partners around the country to preserve NOAH. The fund started with $\$ 100 \mathrm{~m}$ in equity and seeks to 'quickly and efficiently' acquire multifamily buildings. As of 2017 it holds 2,600 units with \$244 m in value across 41 markets. The goal is to achieve 12,000 units by 2020 and to have an additional $\$ 300 \mathrm{~m}$ in equity.

- Program targets. HPET acquisition targets include: market-rate affordable buildings (unsubsidized) of 150300 units; expiring LIHTC buildings; and smaller (under 150 units) buildings held by the GSEs. The buildings are Class B and Class C properties with rents averaging affordability for households earning 80 percent of AMI.

HPET operates across the country, including in 'secondary' real estate markets. Properties tend to be in 'high opportunity' neighborhoods at risk of gentrification. Proximity to schools, transit, and jobs are part of the opportunity concept.

The REIT's acquisition team monitors deals with information via its nonprofit members, who seek to act quickly to compete against for-profit actors.

- Financing Structure. The HPET's institutional investors are social investors; they agree to the REIT's financing for the long term. That means there is no date for property sale; the income to investors come from the stream of rents in buildings that are now well-managed by competent nonprofits.

- Challenges. HPET is currently working to demonstrate liquidity for its investors; since buildings do not sell in this program, they have to make shares in the REIT tradeable so investors can enter and exit the fund.

\section{Sources:}

- "Capital for Communities" report by Philadelphia FED.

- "Minding the Gap in Affordable Housing." REIT news. Dec 2016.

- Ades, D. "Preserving Existing Affordability through a Social Purpose REIT." Journal of Case Study

- Research: A publication of the Center for California Real Estate. Summer 2016.

\section{Austin's Affordable Central Texas Fund}

Impetus and goals. Mayor Steve Adler prioritized the preservation of not only affordable hosuing, but also music venues and other cultural spaces in his election campaign. After an initial investment of $\$ 150,000$ to study the potential structure for a "strike fund" the nonprofit Affordale Central Texas was created this year. Affordable Central Texas will administer the private investment fund for preservation of "middle income housing."

- Program targets. The Austin Affordable Fund intends to purchase existing multifamily NOAH, targeting housing serving 60-120 percent of AMI. The fund average income target will be 80 percent AMI serving units. Housing purchased through the AAF will be in 'high opportunity' areas that are transit rich, and it aims to address gentrification.

- Financing Structure. Not yet disclosed. The Mayor's office states that "this will be a market driven investment-neither subsidized nor philanthropic and not at taxpayer cost."

- Challenges. The fund has not yet been in operation. It is also unclear whether this or other organizations will address cultural preservation, which is a priority for some advocates.

- More Information: http://www.affordablectx.org/ 


\section{Conclusion}

The great majority of the Portland region's low and moderate income renters do not receive government subsidies or live in regulated affordable housing. They live in Naturally Occurring Affordable Housing — here defined as apartments with lower quality ratings that are usually older and with fewer amenities.

As the population grows, and higher income renters move to the area, preserving the stock of NOAH housing is important for the stability of these low income renting households. As new transit lines are planned, loss of $\mathrm{NOAH}$ also means a reduced ability to access opportunities in neighborhoods near transit.

This report focuses on the inventory and market for $\mathrm{NOAH}$ type multifamily buildings. While the region still has a substantial amount of two and three star buildings compared to newer, luxury type apartments, these lower cost units are under pressure. Rents are rising; and sales of buildings have been rising since the recession. With increasing demand to live in the area, the market moves towards investing in and upscaling these $\mathrm{NOAH}$ buildings, which could lead to the displacement of thousands of residents. 